\title{
CUESTIÓN CATALANA Y CRISIS CONSTITUCIONAL
}

\author{
JUAN F. LÓPEZ AGUILAR \\ Catedrático de Derecho Constitucional \\ Universidad de Las Palmas de Gran Canaria
}

\begin{abstract}
SUMARIO
I. Introducción. II. El objetivo, inaplazable: reforma constitucional, ahora. III. El método, y su polémica: ¿reforma constitucional o cortes constituyentes? IV. La definición, estratégica: la secesión catalana como amenaza, y la fortaleza propuesta: hacia una nueva fusión de federalismo y constitucionalismo. V. El marco conceptual, revisado. VI. El apremio de los tiempos: ¿estamos los españoles a tiempo de federar? VII. El horizonte: el futuro de cataluña no es el siglo XVIII, sino el siglo XXI. VIII. Conclusión provisional: hasta luego, independencia, hola constituyente constituido. IX. Epílogo: ¿a tiempo de salvar al TC?
\end{abstract}

\section{INTRODUCCIÓN}

\section{1. ¿Ciclo constituyente? El otro mito del consenso constitucional}

El 20 de noviembre de 2015 hizo 40 años de la muerte del General Franco, llave de paso a la proclamación de Juan Carlos I y la apertura de ese ciclo que dio en llamarse «Transición». Coincidía esta efemérides del tiempo trascurrido prácticamente las mismas cuatro décadas que duró la dictadura - con una ofensiva nunca antes conocida de desmitificación de aquella misma Transición.

Aunque muchos de los españoles vivos no fuéramos «protagonistas» de aquellos tiempos convulsos y preñados de esperanzas —apenas seríamos niños o adolescentes los nacidos en los 60, que seguimos siendo la franja más gruesa de la pirámide de población de la sociedad española, ahora en el entorno de los 50-, seguramente somos otros tantos millones los que encontramos no sólo injusta y falaz sino también ofensiva la descalificación global de aquel período que tanto eco ha encontrado en estos últimos años: la que ha venido a releerla como un «apaño entre élites» que dio lugar «desdichadamente» a un nuevo «régimen»: el «del 78». Éste, que todavía dura. 
Pero la democracia constitucional inaugurada en diciembre de 1978 no ha sido ni es, desde luego, ningún «régimen», en el sentido denigratorio y con la vocación derogatoria con que ahora se la infama desde el discurso simplificador puesto en marcha hace unos años, y singularmente enfatizada en la comunicación de esa formación emergente que dio en llamarse Podemos.

Antes bien, en el transcurso de estas décadas, España ha visto no sólo germinar las libertades sino también consolidarse el pluralismo político y la desconcentración y descentralización del poder político como nunca antes en nuestra historia. Cierto que «el poder» no es solamente «político», ni reside sólo en los gobiernos — nacional, autonómicos y locales—, sino en otras variadas instancias económicas, financieras, empresariales y mediáticas que en ningún caso se someten al escrutinio de las urnas. Pero las urnas, en España, han funcionado como nunca bajo la Constitución de 1978.

Bien a pesar de esa certeza contrastada por los hechos y datos de nuestra historia, la «revisión» de los llamados «mitos» de la Transición ha conocido, en el tramo de estos últimos años, una virulencia también desconocida.

Cuando se leen atentamente las intervenciones y textos de los principales dirigentes de Podemos —un ejemplo: «Disputar la democracia», ensayo de Pablo Iglesias (Akal, 2014) - se observa con claridad que el hilo conductor de su debelación del así llamado «régimen del 78» descansa en un paralelismo —a mi juicio tan artificioso como históricamente sesgado- entre la Restauración canovista (1874) que dio lugar a la Constitución de 1876 y a sus casi cinco décadas de turnismo entre conservadores (Cánovas y sus epígonos) y liberales (Sagasta, y los suyos...) hasta el golpe de Estado y la sucesiva dictadura del general Primo de Rivera en 1923, con la reinstauración de una democracia en España bajo la Constitución de 1978 y la alternancia en el Gobierno de opciones de centro, derecha e izquierda en las sucesivas elecciones desde entonces: ¡Subráyese, para empezar, que no fue la II República el colapso del turnismo inaugurado en 1876, sino aquella dictadura del general Primo de Rivera! ${ }^{1}$

Tal desmitificación de la Transición arranca de una conjetura contrafactual, si es que no directamente ucrónica. Pero de tanto repetirse ha venido siendo asimilada por cada vez más gente, en un entorno creciente de confusión, memoria flaca y desmemoria cada vez más extendidas. Desde esa contralectura se intenta validar la hipótesis de que en aquellas circunstancias — ihace 40 años! - hubiera sido preferible, y desde luego posible, la «ruptura» como alternativa práctica a lo que resultó ser «reforma». Y de que, por consecuencia, habría sido entonces posible apostar directamente por la República — forma de Estado alternativa a la «monarquía parlamentaria» del artículo $1.3 \mathrm{CE}-$ y por el federalismo, alternativa práctica a nuestro "principio autonómico», en tenso debate, cuando menos, con el confederalismo y por extensión con un supuesto (en 
rigor inexistente) «derecho de autodeterminación» de los pueblos del «Estado español».

Las páginas que siguen arrancan de una premisa: la tesis deslegitimadora de la Transición como «trampa» sucedánea del «óptimo» de la ruptura debe ser refutada. Sin que, ello no obstante, la contundencia de esa contestación equivalga, sin más reflexión, a la prolongación acrítica e indefinida del status quo descrito y fijado, tal y como ahora está, pasados 40 años.

Sí, es un despropósito lucubrar que «otra Transición» con «ruptura» en la salida del franquismo (y con «ajuste de cuentas» a quienes tuvieron cualesquiera responsabilidades en la larga dictadura) no fue posible, además de deseable, sin más, porque así se conjuró una amalgama de «élites» y «cliques» endogámicas ¡PSOE y PCE incluidos!

De acuerdo con estas tesis, el conjunto de las fuerzas sociales y sindicales y la dirección de los partidos que emergían de la clandestinidad y la oposición al franquismo habrían conformado entonces la pomada germinal de una «casta» autorreferencial. Ello supondría ignorar no solo los sacrificios inevitables de entonces sino también hechos contrastados, como que, por ejemplo, en 1974, el PCE impulsó la «Junta Democrática» mientras el PSOE apostó por su propia alternativa, la «Plataforma Democrática» (1976), bajo la presión de converger en una llamada «Platajunta».

Lo históricamente cierto es que en ninguno de esos vectores se abrió paso en aquel tiempo la hipótesis de una «ruptura» que abocase directamente a la confrontación, mediando la sublevación potencial de las fuerzas represivas y la movilización y/o huelga general de las organizaciones sindicales y políticas en clave insurreccional contra los decadentes aparatos regimentales del franquismo, bajo la amenaza cierta del mando reaccionario del Ejército de entonces, y bajo el fuego cruzado de la violencia instigada desde el «Bunker» (la extrema derecha inmovilista y la violencia de los grupúsculos fascistas) y los terrorismos de ETA, GRAPO y FRAP (entonces todavía activos).

Sí que hay, y persiste, sin embargo, un «mito» de la Transición que aún debe ser desmontado. Un mito constitucional que se presta a discusión. Este «otro mito» es el que pretende que el «consenso constituyente» —atmósfera en que se alumbró el pacto constitucional- fue entonces la premisa inicial del ciclo constituyente. Y que, consiguientemente, ese exigible «consenso» previo a la propia apertura de un ciclo constituyente sigue siendo todavía y ahora, 40 años después, la premisa irrenunciable de cualquier operación de reforma constitucional.

Pero no. Ni es así ahora ni lo fue entonces, a finales de la década de los 70 del pasado siglo xx. La historia enseña otra cosa. Aquel «consenso» no precedió a la Constitución de 1978. Hubo que trabajarlo minuto a minuto, día tras día, durante años intensos - 1976/1978-. Con esfuerzo, sudor, sacrificio y renuncias, por parte de todos los actores -económicos, sociales, políticos y culturales en buena parte obedientes al cruce de miedos recíprocos y temores compartidos ante 
la perspectiva de desastre colectivo en caso de que no se abriesen espacios para un acuerdo ${ }^{2}$.

Aquel «consenso» no fue previo a la Constitución de 1978: fue el precipitado de la voluntad de acordar desde el mutuo reconocimiento de los actores políticos diferenciados y de sus posiciones enfrentadas.

La lección es pues muy clara: durante todo este tiempo ha sido, sigue siendo $\mathrm{y}$ es lisa y llanamente absurdo pretender que «no puede acometerse ahora una reforma de la Constitución» porque «no hay consenso previo».

Si en 1976 se hubiera argumentado así, la Constitución del 78 no hubiera sido posible tan sólo dos años después. Aquel consenso de entonces hubo que trabajarlo sudando la camiseta, y el que quiera que venga habrá que trabajarlo de nuevo. Con las lecciones aprendidas durante estos 40 años. Y desde la madurez democrática conquistada desde entonces.

Estas páginas sostienen que hay que ponerse ello. Hay que ponerse manos a la obra. Ningún acuerdo cae del cielo. Pero cualquier alternativa a un acuerdo es, sin duda, peor o mucho peor: un sostenido desacuerdo puede derivar fácilmente $-\mathrm{y}$ es muy probable que lo haga - en un desentendimiento político cronificado; en crispación; en esclerosis institucional, larva de inmovilismo; de petrificación del descontento, desafección democrática, malestar social; y, en última instancia, alienación del sentimiento compartido de pertenencia a un espacio de identidades compatibles, múltiples o compartidas, abismado a una tensión de segregación y exclusión mediante la «desconexión» de todo cuanto nos unió hasta entonces.

Esta es la coordenada de la «cuestión catalana» — que alcanza un nuevo punto álgido en la autoproclamada «desconexión» catalana (Resolución del Parlament de Cataluña de 9 de noviembre de 2015) — como ocasión impostergable de una ambiciosa operación de reforma constitucional. Esa «cuestión catalana» no es su causa exclusiva ni su único motivo; sí, desde luego, una ocasión y una oportunidad: una cita con la historia a la que los españoles de todas las «generaciones vivas» sobre las que escribió Thomas Jefferson no podemos fallar.

\section{Por qué reformar la Constitución. Y por qué federalizar: la «cuestión catalana» en la crisis constitucional}

Asumámoslo. El edificio constitucional inaugurado en España en 1978 rechina hoy por todas las costuras. Tras casi 40 años, urge rehabilitarlo, y eso exige reformarlo ${ }^{3}$.

2 Véase por todos: Morodo LeOncio, R.: La transición política, Tecnos, 1984

3 Sobre la problemática general de la reforma constitucional, el escrito clásico de MoRTATI, C.: «Concetto, limiti e procedimento della revisione della Costituzione», en Riv. Diritto Pubblico, 1952. 
Reforzar la democracia - maltrecha, como los derechos, por el manejo de esta crisis que hemos dado en llamar «Gran Recesión» europea-, restablecer el crédito de la política y relanzar al mismo tiempo su capacidad de integrar la pluralidad y el conflicto, son objetivos que demandan un pacto constitucional que actualice el que se hizo hace ya tanto tiempo. Y un pacto federal que asuma - va siendo hora - la maduración de nuestra diversidad identitaria, que es la de los españoles en esta primera mitad del siglo XXI. Y la encaje en un proyecto inclusivo para «acabar» de una vez lo que resta inacabado en el modelo autonómico ${ }^{4}$.

De modo que, para empezar: ¿De qué hablamos cuando hablamos de federalizar? La idea federal reside en pactar una Unión, compuesta entre un todo (el Estado federal, el Bund) y sus partes (los estados federados, Länder, CC.AA, o provincias como en Canadá), pero sobre todo consiste en hacerlo constitucionalmente: ¡en la Constitución!

La adjetivación federal se presta, sí, a controversia («social», «solidario», «plurinacional», «asimétrico»...). Esos arquetipos contraponen procesos federales distintos entre sí: los hay de la diferencia como los hay de igualdad, dependiendo de qué asunto pongamos en comparación.

Dicho con otras palabras: no hay dos federalismos idénticos; no hay un «canon» federal sino experiencias federales decantadas por la historia y por la realidad. Ninguna es replicante de otra: véanse las variaciones entre los Senados como «segundas Cámaras» en Estados federales. Las une, sin embargo, un rasgo: en las Uniones federales, el reconocimiento de la pluralidad constitutiva del todo y la regla del reparto de competencias y la financiación de sus miembros queda establecida en la propia Constitución ${ }^{6}$.

Y eso, lisa y llanamente, no ha pasado en España desde 1978. Y continúa hoy sin suceder, puesto que el Estado autonómico no está en la Constitución (en cuyo texto esa expresión no aparece por ninguna parte) sino que fue desarrollado con posterioridad. Lo han hecho los Estatutos, las leyes (sobre todo las básicas) y la jurisprudencia (mutante) del TC en el llamado «bloque de constitucionalidad». Funcionó, mientras lo hizo. Pero hoy los indicadores de que ese motor se ha gripado son ya, hace tiempo, clamorosos ${ }^{7}$.

4 Solozabal, J.J. (coord) et al.: La Reforma federal. España y sus siete espejos, Biblioteca Nueva, Madrid, 2014.

5 Cfr. Wheare, K.C.: Federal Government, 4. ${ }^{a}$ ed., New York, Oxford University Press, 1963; De Vergottini, G.: Derecho constitucional comparado, Espasa-Calpe, Madrid, 1983; DION, S.: «El federalismo fuertemente asimétrico: improbable e indeseable», en FossAs, E. y ReQueJo, F.: Asimetría federal y Estado plurinacional. El debate sobre la acomodación de la diversidad en Canadá, Bélgica y España, Madrid, Trotta, 1999; Lopez Aranguren, E.: El federalismo americano: Las relaciones entre poderes en los Estados Unidos, Madrid, Instituto de Estudios de Administración Local, 1987.

6 Blanco Valdés, R.L.: El valor de la Constitución: separación de poderes, supremacía de las leyes y control de constitucionalidad en los orígenes del estado liberal, Alianza Editorial, 3. a ed., 2006; Los rostros del federalismo, Alianza, Madrid, 2012; López Aguilar, J.F.: Estado autonómico y bechos diferenciales, CEPC, Madrid, 1998.

7 Véase, sobre estos dilemas, Aja Fernández, E.: El Estado autonómico: federalismo y hechos diferenciales, Alianza Editorial, 1999; Rubio, F.: («El bloque de constitucionalidad»), L. PAREjo («Constitución y valores 
A partir de ahí, dos activos principales de la propuesta federal contribuirían a encarar la tensión secesionista en Cataluña.

Federalizar, primero, supondría una oportunidad de enorme impacto simbólico (delinea un cambio de época para la reintegración generacional e identitaria en España). Desde el punto de vista político, reordenar constitucionalmente la estructura del Estado sería la única manera de acomodar la singularidad catalana con los demás pueblos de España. Jurídicamente, liquidaría de una vez por todas el carácter transitorio de buena parte de la Constitución, eliminando la «grasa» obsoleta e inutilizable de su Título VIII. Sería, en definitiva, la ocasión de «acabar» de conformar lo que, por razones históricas y prejuicios psicológicos, no fue posible en los 70. Y de «cerrar» con un pacto el indefinidamente abierto principio dispositivo, que no es sino la inconcreción del número de CC.AA y de sus competencias, y la incapacidad de asumir las diferencias entre ellas sin sujetarlas al juego de emulación competitiva entre liebres y tortugas. Un ejemplo palmario de sus efectos lesivos reside todavía hoy en el artículo 150.2 CE: precisamente, el invocado en su día por el Parlament de Cataluña para reivindicar por Ley orgánica la transferencia del Estado de la competencia para convocar una «consulta» de autodeterminación que escindiría a los catalanes contra sus identidades múltiples, incluyendo la europea.

Federalizar la Constitución permitiría así incorporar a todos los españoles —en especial, a los más jóvenes, que ni siquiera habían nacido cuando se votó la Constitución - al objetivo impostergable de relanzar la democracia y la participación de la ciudadanía en la reformulación de nuestra pluralidad, desde la supranacional hasta la identitaria, en lo territorial. Sólo una reforma constitucional a fondo, que auspicie un nuevo Estatut, votado — una vez más— por el pueblo de Cataluña, daría una respuesta aceptable a la demanda de reconocimiento y diferenciación que ha germinado, asumámoslo, en la sociedad catalana. Y la revisión de la Constitución española es el contexto necesario y adecuado para hacerlo.

Pero habría todavía otro efecto ventajoso. Si hay un avance relevante en el constitucionalismo del siglo xxi y la globalización, ése es precisamente el de la superación del tradicional binomio entre la Constitución y el Estado. Desafía la vieja identificación de toda nación con un Estado «soberano»e «independiente».

Se reencuentra así con fuerza la identificación histórica entre constitucionalismo y federalismo: Porque esa, a mi juicio, es la única forma de legitimar, votando, la integración de la complejidad y de las identidades múltiples en estructuras democráticas de gobierno multinivel. La ciudadanía del siglo XXI ya no encaja sin más en el reduccionismo de las fronteras cerradas de viejas «soberanías» (lo que quiera que esto sea en la globalización) confrontadas y excluyentes... aunque re-

del ordenamiento»), L. I. SÁNCHEZ-RodRiguez ( «El artículo 93 y el bloque de la constitucionalidad: algunos problemas») y J. A. CARRILlo («Funciones del Derecho internacional contemporáneo: garantía de la independencia de los Estados e instrumento para la cooperación entre los Estados»), en AA. VV.: Estudios sobre la Constitución española de 1978 en Hom. al Prof. E. García de Enterría, t. I, Civitas, Madrid, 1991. 
sulten virtuales. Requiere, por el contrario, nuevas soluciones, abiertas a lo diverso y a lo compatible: ciudadanía en derechos. Nacional y federal. Supranacional y global $^{8}$.

La Constitución federal puede reconciliar esas identidades, sin que el reconocimiento de la singularidad que Cataluña reclama tenga que abocar a ninguna «estatalidad» catalana «soberana» e «independiente» por confrontación con España y con la UE.

Estamos a tiempo de evitar una frustración de magnitudes históricas en esta «cuestión catalana» que es de todos los españoles, y tenemos el deber de hacerlo. Pero hay que ponerse a ello. La apuesta federal es acción, requiere osadía y coraje para acordar, reconstruir puentes y suturar descosidos. Con vocación de hacer historia, y de cambiarla y liderarla.

\section{EL OBJETIVO, INAPLAZABLE: REFORMA CONSTITUCIONAL, AHORA}

Los últimos días de febrero de 2015 tomé parte en Zaragoza en el Congreso Anual de la Asociación de Constitucionalistas de España. El ambiente en ese encuentro era en sí revelador: en un foro de especialistas de muy distintas afinidades políticas y partidarias, el estado de opinión ampliamente mayoritario entre los profesores, estudiosos e investigadores que hemos dedicado una vida al Derecho Constitucional, era, de largo, favorable a la reforma constitucional. A su necesidad, a su oportunidad y, sobre todo, a su urgencia. La pregunta subsiguiente se formuló muchas veces: si los profesores, desde prioridades y actitudes intelectuales y científicas muy distanciadas entre sí, pueden ponerse de acuerdo... ¿ ¿por qué los políticos no?

Vayamos, pues, directamente al grano, a las conclusiones. Las Constituciones se defienden reformándolas. Preservar la utilidad de los pactos constituyentes de la Transición y de su producto más preciado — la Constitución del 78, particularmente rígida en lo referente a su reforma, y por lo tanto blindada frente a la eventualidad de modificaciones irreflexivas (arts.167 y $168 \mathrm{CE}$ ) — exige ahora, transcurridos nada menos que 40 años desde la muerte de Franco y 37 años desde su aprobación, disponerse a modificarla en lo que haya envejecido o haya perdido actualidad, con altura de miras, luz larga y coraje político?

Eso es exactamente lo que hacen todas las sociedades democráticas avanzadas y maduras. Habrá que recordar de nuevo que la Constitución de EEUU lo ha sido en 27 ocasiones, y la alemana en 59 (por cierto, ninguna de las dos lo ha sido en

8 Balaguer Callejón, F. (coord) et al: Reformas Estatutarias y Distribución de Competencias, Tirant lo Blanch, 2007; y «Una interpretación constitucional de la crisis económica». En Libro homenaje al profesor Rafael Barranco Vela, Vol. 1, 2014, pp. 249-256.

9 García Roca, J. (coord) et al.: Pautas para una reforma constitucional, Aranzadi, 2014. 
ningún caso por la vía de un referéndum)... Y que las Constituciones francesa, italiana o portuguesa (piénsese que Portugal transitó a la democracia desde una larga dictadura en circunstancias parejas a nuestras propias dificultadas) han experimentado reformas con normalidad democrática que no sólo no han perjudicado el crédito y la solidez de sus sentimientos constitucionales sino que los han relanzado ${ }^{10}$.

Personalmente, hace tiempo que sostengo, con toda la carga de crítica, que la actitud de un segmento significativo de los sectores más conservadores de la sociedad española — negándose no ya a reformarla sino ni siquiera a abrir el debate y el ciclo político para ello- viene perjudicando el crédito a la Constitución: en lugar de protegerla, ha deteriorado su virtualidad integradora; y la capacidad de integración política es un capital principal de toda Constitución. En ese preciso sentido, la cerrazón de buena parte de la derecha política y mediática se ha vuelto contraproducente a la prolongación del aliento vital de la Constitución de 1978 en todos los sentidos imaginables.

A la vista de que esto se ha dicho tantas veces y desde tantas tribunas, resulta particularmente cínico ese argumento, tan socorrido, por el que una y otra vez desafían abiertamente a los defensores de la reforma constitucional a que les «digan de una vez» qué es lo que se quiere «modificar», o «que les digan qué artículo concreto haría falta reformar».

Sorprende la contumacia de esta actitud tan refractaria a toda reforma constitucional. Para empezar su refutación, la literatura académica sobre la obsolescencia de una gran parte del articulado y pérdida de actualidad de la Constitución de 1978 resulta ya inabarcable. Profesores y especialistas de todas las tendencias coinciden en la conveniencia no sólo de abrir el debate, sino de emplazar sobre la mesa un prontuario de cuestiones que deberían discutirse y solventarse cuanto antes. Y en que el compromiso que se contrae en la apertura de ese ciclo no anticipa el resultado: he escrito numerosas veces que es falso que el consenso constituyente preceda a la conversación sobre la Constitución... ni en 1978 ni ahora, casi 40 años después. El consenso no es premisa ni precondición de una operación constituyente o de reforma, sino su desembocadura. Así fue y así se hizo a fines de los 70. Y así debería hacerse ahora.

Los objetos preferentes para una eventual reforma constitucional varían, por descontado, según quién y sobre qué opine de cada asunto, en función de las prioridades políticas y de los valores y motivos de cada uno de los partícipes de un debate plural. Y no podría ser de otro modo en una sociedad abierta. Pero lo revelador es que todo el mundo pueda señalar con claridad y precisión qué piezas de la desgastada arquitectura constitucional muestra a estas alturas una más acu-

10 ARroyo GIL, A.: El federalismo alemán en la encrucijada: sobre el intento de modernización del orden federativo en la República Federal de Alemania, CEPC, Madrid, 2006; La reforma constitucional del federalismo alemán, Barcelona, IEA, 2009; HESSE, K.: Escritos de Derecho constitucional, comp. y trad. de P. Cruz Villalón, CEC, Madrid, 1983. 
sada fatiga de materiales... y requerirían un debate que apuntara a su restauración con retoques para su mantenimiento ${ }^{11}$.

En este contexto, algunas fuerzas políticas llevan unos cuantos años acrisolando una posición ampliamente favorable a la reforma constitucional. Más concretamente, ya en 2004 el PSOE concurrió a las elecciones generales con cuatro objetos identificados para una propuesta de reforma constitucional que, más de diez años después, continúan siendo válidos hoy: propugnábamos entonces introducir en la CE una «cláusula Europa», la remoción de la preferencia del varón sobre la mujer a la sucesión de la Corona, constitucionalizar el Estado Autonómico (identidad, competencias, financiación y cooperación e integración política de la diversidad) y, cómo no, como siempre la «reforma del Senado».

Sólo que hoy, tras los trabajos que condujeron a su Conferencia Política de 2012, la apuesta socialista por la reforma constitucional es más amplia y profunda. De modo que la actual propuesta incluye hoy, sin ambages, una expresión de voluntad de constitucionalizar una «España federal». Federalizar España, sí. Porque, a pesar de los prejuicios históricamente arraigados en España, «federar» no es «desunir»: al contrario, es pactar, y hacerlo en una Constitución que garantice jurídicamente una unidad y la voluntad de vivir juntos de las partes (las CC.AA) y de los ciudadanos que integran la Unión federal. Y federar es unir, y hacerlo con la Constitución ${ }^{12}$.

Por varias razones procede, efectivamente, federalizar la España que hoy llamamos «autonómica». Cuando menos, las siguientes:

1. El reconocimiento de la pluralidad constitutiva de España no encuentra mejor formulación que la solución federal: esa es la enseñanza clara del constitucionalismo histórico y comparado, y de los mejores ejemplos de integración política en sociedades abiertas y comunidades plurales en democracia avanzada.

2. El actual Título VIII CE, «De la Organización territorial del Estado» (que, no lo olvidemos, por ninguna parte constitucionaliza ningún «Estado autonómico» ni «de las Autonomías» sino que sólo lo hizo posible), es todo él, a estas alturas, un Título de Derecho Transitorio: los arts. 146, $147,148,149$ y $150 \mathrm{CE}$, entre otros, son enunciados «dispositivos» que, una vez que fueron puestos en práctica en su día (finales de los 70 y principios de los 80), quedaron sobreseídos por la acumulación de posteriores convenciones aplicativas y por la jurisprudencia definitoria del denominado, en la jurisprudencia del TC, «bloque de constitucionalidad». Pro-

11 Cfr. García Roca, J. (coord) et al.: Pautas para una reforma constitucional, Aranzadi, 2014.

12 Blanco VAldés, R.L.: El valor de la Constitución: separación de poderes, supremacía de las leyes y control de constitucionalidad en los orígenes del estado liberal, Alianza Editorial, 3. a ed., 2006; BisCARETTI Di RuFFIA, P.: Diritto Costituzionale comparato, Giuffré, Milán, 1984; Bogdanor, V.: Constitutions in Democratic Politics, Gower, 1988. 
cede, pues, eliminar cuanto reste todavía de «Derecho Transitorio» como si fuese un arma para un solo disparo- en el actual Título VIII de la Constitución.

La pertinaz negativa de una formación cualquiera con opciones de gobierno a abrir siquiera el debate sobre la reforma constitucional la inhabilitaría para aspirar a liderarlo. Y no solo en Cataluña, donde el activismo político que ha dado en llamarse soberanismo/independentismo, rayano en ocasiones tensas en el unilateralismo (lo que en la doctrina canadiense dio en conocerse como UDI, «Unilateral Declaration of Independence»), ha sido también espoleado y azuzado por una irresponsable estrategia que fue en su día diseñada y ejecutada por la dirección del PP (secundada en esto, por cierto, por un atronador coro mediático) para dinamitar el Estatut de 2006.

A mi juicio, el grave daño causado por esta estrategia se manifestó en tres planos:

Primero, porque el Estatut de 2006 (el mismo que, tras la largamente retrasada STC 31/2010, continúa hoy en vigor, no se pierda de vista) fue, como ahora opinan, una última ocasión para intentar integrar el hecho diferencial e identitario catalán en una España autonómica convocada a superar el tiempo del «café para todos»; al malograrse ese designio, se ha generado una creciente ola de desafección a las hechuras heredadas del pacto constituyente, cuya magnitud epocal, especialmente incidente en la población más joven, carece de precedentes desde la Transición ${ }^{13}$.

En segundo lugar, porque el mismo Grupo de diputados del PP que recurrió ante el TC la práctica totalidad del enjundioso articulado del Estatut catalán de 2006 (237 arts.), dijera y votara sí al Estatuto Valenciano de 2006 e incluso al de Andalucía de 2007 (intentando reparar su «pecado original» de haberse opuesto al referéndum de 1980) —ambos textos normativos con cláusulas identitarias y competenciales análogas en muchos puntos a los del Estatut catalán, pero no impugnadas estas últimas por el PP-. Con esta contradicción, la derecha ha desatado un sentimiento de agravio comparativo que empeoró con la campaña de «recogida de firmas» en todo el resto de España contra el Estatut catalán, y exasperó aún más la explotación política de viejos y larvados prejuicios anticatalanes tristemente arraigados en un sector significativo cada más recalcitrante de una derecha mesetaria que se ha mostrado crucial, en ocasiones clave, para el reagrupamiento del electorado del PP.

En tercer lugar, aquella estrategia se llevó por delante, en una irreparable medida, el propio prestigio del TC (con la recusación del magistrado Pérez Tremps y de la Presidenta del órgano, $\mathrm{M}^{\mathrm{a}}$ Emilia Casas). Y sucede que sin un TC

13 Cfr. mi comentario a la sentencia citada en López Aguilar, J.F.: «La sentencia más larga. Repercusiones de la STC 31/2010: política y jurisprudencia», Teoría y Realidad Constitucional, n. ${ }^{\circ} 27,2011$. 
en condiciones no hay Constitución normativa que se mantenga en pie. Tal daño colateral debió haber sido previsto. Porque, tras el desdichado episodio de las impugnaciones políticamente interesadas (seguidas de una errática política de nombramientos para la renovación del órgano, condicionada por la obsesión de asegurar en el TC el desmantelamiento de las decisiones del Gobierno socialista y la revalidación de los decretos leyes y recortes adoptados después de las elecciones de noviembre de 2011), el desmoronamiento del prestigio del TC ha sido incremental, irreversible y letal para el propio crédito de la Constitución como instrumento de integración política.

Pero no acaba ahí el relato de los yerros dañinos de aquella estrategia política. Porque, llamativamente, otro de los argumentos más manidos por parte de los sectores más «conservacionistas» del actual status quo para persistir en su cerrazón obcecada y su negativa a abrir siquiera el debate de la reforma, consistiría en una suerte de inversión taimada de los términos de la ecuación por la que el deterioro de la confianza en las instituciones y de la propia convivencia democrática no solo no aconsejarían «coger el toro por los cuernos» y liderar las reformas que dieran respuesta a ese clima, sino que, antes al contrario, se trastocarían incluso en un mantra disuasorio contra la idea de intentarlo. De modo que, precisamente porque la «democracia está en crisis»... «ahora no es el momento». Aplicando la máxima ignaciana — «en tiempos de tribulaciones, mejor es no hacer mudanza»— esa actitud refractaria viene arrellanándose en «la crisis» para posponer sine die una demanda de reformas que, de tan manida, corre desde hace tiempo el riesgo de italianizarse: envejecer sin resolverse, hasta que se pase el arroz.

Tal subterfugio argumental viene rezando como sigue: «Ahora no es el momento»... «la gente no está pensando en reformas constitucionales»... «hay que luchar contra la crisis»... Lo cierto es que para algunos «nunca es el momento». De hecho, «nunca» lo ha sido al menos para una buena parte de la derecha española en 40 años de democracia.

$\mathrm{Da}$, en efecto, la impresión de que para ese sector de la derecha española más refractaria a los cambios — en muchos sentidos heredera de aquélla que llegó tarde y mal al pacto constituyente, y que en una amplia medida no la votó o votó «no» a la Constitución - nunca «será» ese momento de hablar de eventuales reformas... salvo que se le fuerce desde un liderazgo externo a su control y a su perímetro.

Enlazaría esta letanía con otro argumento socorrido pero igualmente refutable: ni la «reforma federal» de nuestro Estado autonómico ni ese «federalismo» que propugnaría últimamente la propuesta socialista, lograrían «contentar» nunca a los nacionalistas. Desde esa perspectiva, ninguna reforma constitucional aquietará por sí sola los nacionalismos independentistas. Se oculta bajo este subterfugio que el objetivo del federalismo no es «aplacar» a los independentistas hasta una «próxima estación», sino liderar y acordar una efectiva puesta en hora de la organización territorial del Estado, cuyos desfases, obsolescencias e ineficiencias rechinan por todas las costuras. Y hacerlo no porque lo demanden los que se sitúan 
en claves nacionalistas o independistas, sino para promover una alternativa propia, orientada a asegurar la unidad constitucional federal y a relanzar la capacidad de integración de la diversidad y las singularidades que toda Constitución tiene el deber de cumplir en una comunidad política.

$Y$ es que lo cierto es que este enfoque es en sí mismo de un rancio y españolísimo prejuicio conservador que, equivocadamente, rechaza el «federalismo» por entenderlo conexo con los impulsos de cambio que en la historia de España encarnaron en su día fuerzas y actores «progresistas» (toda vez que monarquía y centralismo se dieron cita en nuestra historia desde que Felipe V se proclamó vencedor en aquella guerra civil que dimos en llamar «Guerra de Sucesión», 1700-1714).

Pero se vincula a su vez con otro mantra disuasorio contra la oportunidad de liderar las reformas: el que pretende que la sola hipótesis de «reformar» no sería sino una forma de secundar el discurso de «demolición» de — por ejemplo— «Podemos»... y de «los populismos», ese nuevo «fantasma» que, parafraseando a Marx, recorre Europa y sus Estados miembros a rebufo de la agónica crisis que arrancó en 2008.

Y, sin embargo, no es así. No es verdad. Lo único democráticamente comprobado es que si desde los partidos con opciones contrastadas de gobierno no lideras la reforma y declinas la oportunidad hasta que se va de las manos, entonces sí que estás optando, sin remisión, por que «te hagan» la reforma—es decir, que te la impongan- en lugar de hacerla tú. Y te la harán además por la peor vía posible: no la de la «reforma» de la Constitución en lo que sea acordado y menester, sino de la cancelación del «Régimen del 78»... como si fuera cierto que la Constitución de 1978 hubiera devenido un remedo del turnismo entre los conservadores Cánovas y los liberales de Sagasta, muñido por los caciques y oligarcas provinciales, tras la Restauración canovista y la Constitución de 1876.

Esa falacia, insisto, debe ser refutada: ignora dolosamente las diferencias históricas entre la soberanía popular (art.1.2 CE) y la «doctrinaria» de entonces (que residía en el Rey con las Cortes, según la Constitución de 1876), entre sufragio censitario (el del siglo XIX) y sufragio universal (el que rige desde 1978), entre la alternancia democrática (oposición y derrota del partido en el Gobierno, como ha sucedido en España bajo la Constitución de 1978) y aquel turnismo pactado, con elecciones amañadas por oligarcas y caciques después de que el Rey se aviniese a cada turno en el Gobierno y no antes, como sucedía en la vigencia de la Constitución de 1876.

Llegados hasta aquí, y visto lo visto, resulta dolorosamente lamentable que en la historia de España no haya arraigado una cultura y práctica de las reformas y de las modificaciones constitucionales de acuerdo con las propias reglas establecidas en las Constituciones en cada momento en vigor.

Basta releer a Galdós para abismarse a la evidencia de que cada Constitución se edificó sobre los escombros de las anteriores, de que cada «nuevo orden» se abría paso demoliendo a golpes las situaciones constitucionales previas...Y nor- 
malmente después de la recurrente disrupción de asonadas, cuartelazos, pronunciamientos, sublevaciones, «alzamientos», fusilamientos masivos, guerras civiles, guerras una y otra vez, y enorme derramamiento de sangre, llevándose, desde hace siglos y hasta bien entrados en el turbulento siglo $\mathrm{xx}$, a muchos inocentes por delante.

¿Acaso los españoles no haremos buenas esas lecciones de la historia, aprendiendo de una vez a reformar civilizadamente nuestras constituciones conforme a sus propias reglas como hacen todas las democracias de nuestro entorno a las que siempre quisimos parecernos: Alemania, Francia, Italia, Austria...? ¿Y como ha hecho incluso Portugal, que transitó a la democracia en paralelo a España, desde una prolongada dictadura, con su Constitución de 1976, varias veces reformada?

Todas esas democracias sólidas de nuestro entorno han sido capaces de abrir debates y ciclos de reforma de sus Constituciones, sin quebrantos no resueltos... Y por supuesto sin practicar un reaccionario fetichismo constitucional, ese mismo que en España ha caracterizado tanto a una derecha que lo practica sobre la letra de la Constitución (que no sobre su «espíritu») con la misma furia del converso de quienes dicen «querer» mucho aquello que no se entiende ni se practica, e invocan demasiado a menudo la Constitución de 1978 sin haberla leído, o ignorando sus valores más exigentes, o trastocándola en martillo con el golpear a los supuestos «herejes», «desleales» o «desafectos» a cuantos reformistas, progresistas o radicales eran antes estigmatizados como «traidores», «sediciosos», cuando no como «malos españoles».

Es la hora de argüir que, de lejos, la peor opción frente al independentismo es el inmovilismo. "No hacer nada», dejarles en campo abierto la hegemonía discursiva y narrativa sobre el solar del descontento y de la desafección, sin ninguna resistencia, y por incomparecencia de ninguna alternativa mínimamente sugestiva, es constitucionalmente suicida.

Lo que los federalistas proponemos es una unidad federal, pero siempre una unidad, de ciudadanos y territorios. Regida por una Constitución normativa, jurisdiccionalizada, y democráticamente legitimada.

Porque federalizar España es apostar no sólo por un nuevo «arranque fresco», sino también por abrir paso a una nueva narrativa. $Y$ es recuperar la iniciativa en materia de la propia idea de España, con vocación de liderazgo.

La realidad actual, tal y como evidencian los estudios demoscópicos, es que una parte sustancial de la sociedad española como «sociedad avanzada» — profundamente transformada en lo demográfico, social, generacional, cultural y socioeconómico respecto de sus parámetros hace casi 40 años- es que la España plural ya no se siente reflejada en los envejecidos mimbres de la Constitución de 1978 y de los pactos trabados durante la Transición.

Conclusión provisional: no va a ser, seguramente, ese sector de pensamiento conservador más opuesto a cualquier hipótesis de reforma quien acometa esta tarea tantas veces aplazada. Por descontado que no. Pero sí, en cambio, las fuerzas políticas más comprometidas con los cambios necesarios (muchos ellos revestidos de aura 
«generacional» en la lectura sociológica que se va haciendo dominante) deben positivamente asumir el liderazgo en el proceso de reforma. Deben liderar la reforma y el debate de reforma de la Constitución. Y para ello había hasta hace poco dos opciones: una, haber activado, a finales de la X Legislatura (2011-2015), la interposición de una iniciativa parlamentaria de reforma constitucional (arts.87.2 y 166 $\mathrm{CE}$ ), en modo que, tras las elecciones, se hubiese constituido una ponencia en la Comisión Constitucional, rodeada de un amplio debate social (académicos, profesores, intelectuales, ONGs, organizaciones profesionales, CEOE, sindicatos...). Y dos, iniciarlo desde el arranque mismo de la XI Legislatura (2015-2019). Y hacerlo desde el Gobierno, desarrollando los trabajos a lo largo de los años por delante, en modo que, coincidiendo con su final, se disuelvan las Cortes (art. $168 \mathrm{CE}$ ) y, tras unas nuevas elecciones (final del próximo mandato), tenga lugar el preceptivo referéndum de ratificación. Esta segunda opción es la que permanece en pié.

Y a ese preciso objeto - hay que decirlo, con claridad y osadía— sería útil y oportuno modificar el propio Título X CE (art.168 CE), acabando con la técnica de la hiperrigidez que tanto ha abonado la imagen de una Constitución virtualmente «irreformable». Esa imagen que hace un tiempo que dejó de servir al objetivo de proteger y blindar el prestigio de sus instituciones para deslizarse hacia el riesgo de hacer de la Constitución un edificio averiado, aquejado de fatiga de materiales y aluminosis, y sin embargo demasiado arduo de rehabilitar, espoleando así la tentación facilona de la «demolición» que yace bajo el inquietante discurso derogatorio del «régimen del 78».

Reforma constitucional, pues. Y ahora. Antes de que sea ya tarde.

\section{EL MÉTODO, Y SU POLÉMICA: ¿REFORMA CONSTITUCIONAL O CORTES CONSTITUYENTES?}

En una señal de liderazgo, la propuesta de reforma constitucional en la que el PSOE se ha comprometido en firme desde la Conferencia Política de 2011 y la Declaración de Granada (2013) — que es corolario, a su vez, de la que en su día impulsó el Gobierno de Zapatero y no llegó a realizarse-, ha fijado en la agenda de la XI Legislatura (2015-2019) la oportunidad de abordar un objetivo muchas veces debatido y otras tantas aplazado.

Vengo abogando hace tiempo por la necesidad, a mi juicio inaplazable, de reparar los descosidos que se han venido acumulando en nuestra arquitectura constitucional, cuyo desgaste de materiales rechina ya por casi todas sus costuras.

En particular - y no solo-, procede reformar la Constitución para definir en un sentido expresamente federal el trayecto hasta ahora inacabado (e indefinidamente «abierto») de nuestro Estado autonómico: federar es unir; no segregar ni centrifugar. Y federar es pactar la unión, y hacerlo en la Constitución. Y es hora, tras casi 40 años del ciclo constituyente de finales de los años 70, de que hagamos 
lo que entonces no fue posible hacer, asumiendo de una vez la maduración (tardía) de una democracia herida, pero viva y con futuro.

El debate sobre la reforma continúa, sin embargo, coleando -incluso en el seno del PSOE - en relación con un punto sobre el que sigue haciendo falta un poco de pedagogía.

En efecto, mientras algunos portavoces y dirigentes aluden a la oportunidad de hacer de las Cortes surgidas de las elecciones del 20-D unas «constituyentes», otros subrayan que de ningún modo se busca una nueva «operación constituyente», sino tan solo «reformar» la Constitución vigente, la de 1978, con vistas a relanzar su hoy desgastada capacidad de integración y de marco democrático para la convivencia.

Se trata, en buena medida, de un falso debate sobre el que la teoría constitucional arroja lecciones clarificadoras.

Con orígenes en clásicos como G.F. Jellinek, la teoría de la Constitución ha dado lugar a un desarrollo en la doctrina que, desde K. Loewenstein, distingue entre el «poder constituyente» (originario e ilimitado) que aprueba una Constitución, y el «poder constituyente constituido», que es el «poder de reforma de esa constitución» que actuaría de conformidad a los procedimientos y con las garantías de refuerzo (mayorías cualificadas y eventuales referéndums) que la misma ha establecido para su modificación ${ }^{14}$.

En España, aquí y ahora, es necesario, sin duda, acometer la puesta en hora del texto constitucional. Superando de una vez la fase «procedimental»y «transitoria» del Título VIII que abre paso a la «organización territorial del Estado», y certificando el acta de maduración federal de nuestra integración unitaria de la diversidad y el reconocimiento de los hechos «singulares» de la diferencialidad de la propia identidad y vocación de autogobierno (lenguas, culturas, foralidad, derechos propios, regímenes fiscales propios, e insularidad...).

Pero también, y no menos, hace falta superar de una vez esa atormentada historia que — quiero evocarlo de nuevo- Benito Pérez Galdos historió magistralmente en sus Episodios Nacionales: esa España en la que las Constituciones nunca se sucedieron unas a otras de acuerdo con las reglas previstas para su propia reforma, sino a través de turbulencias o disrupciones abruptas. En definitiva, rupturas que no reformas: cuartelazos, asonadas, pronunciamientos, golpes de Estado, fusilamientos masivos y guerras civiles, fueron invariablemente preludio de cada «nuevo régimen». Es hora de que la Constitución de 1978 madure su propia reforma de acuerdo con sus propias reglas.

14 Sobre la teoría general del poder de reforma de la Constitución, véase MorTati, C.: «Concetto, limiti e procedimento della revisione della Costituzione», en Riv. Diritto Pubblico, 1952; Barile, S.: «Potere costituente», en AA.VV.: Novissimo Digesto, vol. XVIII, Torino, 1966; BRYCE, L.: Constituciones flexibles Constituciones rígidas, IEP, Madrid, 1963; JellineK, G. F.: Reforma y mutación de la Constitución, CEC, Madrid, 1991; Loewenstein, K.: Teoría de la Constitución, Ariel, Barcelona, 1983.

UNED. Teoría y Realidad Constitucional, núm. 37, 2016, pp. 273-308 
La ocasión idónea para ello es el 20-D y las Cortes Generales nacidas de esas elecciones. A partir de estas elecciones, toda la Legislatura en curso (2015-2019/2020) es y será, en sí, tiempo útil para su debate y perfeccionamiento para su aprobación por mayoría de $2 / 3$ de cada Cámara, seguida por la disolución de esas Cortes Generales (art. $168 \mathrm{CE}$ ), su nueva ratificación por $2 / 3$ de las Cortes sucesivas (las elegidas en 2019-2020), y su definitiva ratificación por referéndum de todo el pueblo español ${ }^{15}$.

En otras palabras, con ello se está postulando que el objetivo no sea el de una «ruptura» con derrocamiento o «finiquito» de la Constitución anterior (la de 1978), sino, por fin, una reforma, ahora sí, tan profunda y todo lo intensa y ambiciosa que la actual fatiga democrática aconseja y requiere.

En consecuencia, esa reforma no podría ser cosmética ni limitarse a «retocar» un número reducido de artículos ni podría tampoco adoptarse por la vía simplificada (mayoría de 3/5 sin necesidad de referéndum, artículo $167 \mathrm{CE}$ ) con la que se operaron las dos reformas parciales que tuvieron lugar hasta ahora (art. 13.2 en 1992 y art. 135 en 2011).

La reforma que viene sí que debería ser extensa y profunda. Una reforma en serio. Meditada y adecuada en un ciclo de diálogo, negociación, acuerdo y, finalmente - solo finalmente-, consenso. Un consenso tan ambicioso y valiente como requiere la situación de cansancio de la sociedad y «desenchufe» generacional de los más jóvenes. Y para ello hace falta liderazgo.

Esa reforma cumpliría varios objetivos relevantes —a mi juicio, incluso trascendentes - de manera simultánea.

Particularmente, lo haría por resultar validada por la vía agravada del artículo $168 \mathrm{CE}$, a través de referéndum.

Porque ese referéndum sería en sí mismo el más potente instrumento de relegitimación del propio pacto de reforma constituyente. Momento de reenganche generacional de los jóvenes. Y ocasión de zurcimiento y sutura de los muchos y graves descosidos y rotos que se han producido en Cataluña, cuya envergadura política resulta imposible ignorar.

La aprobación por referéndum de esa reforma constitucional cumpliría, en simultáneo, los siguientes objetivos:

a) Simbólicamente, cumpliría una función de reseteo de una arquitectura constitucional desgastada por el uso y por el paro del tiempo. Y no ha sido en balde.

15 Sobre el procedimiento de reforma de la CE (Título X CE), véase por todos, ConTreras, M.: «La reforma de la Constitución», en AA. VV.: Estudios sobre la Constitución española de 1978, Ed. de M. Ramírez, Zaragoza, 1979; DE VEGA, P.: La reforma constitucional y la problemática del poder constituyente, T-Clave, Tecnos, Madrid, 1985; Jiménez Campo, J. («Algunos problemas de interpretación en torno al Título X de la Constitución», en Revista de Derecho Político, n. ${ }^{\circ}$ 7, UNED, otoño de 1980. 
b) Social y políticamente, cumpliría la función de abrir cauce al reenganche generacional de las cohortes más jóvenes, en las que la narrativa de la Transición ha perdido su eficacia.

c) Jurídicamente, el referéndum permitiría validar el nuevo acomodo de la diversidad y el reconocimiento de las diferencias y las singularidades dentro de la unidad Constitucional española. Función esta crucial en Cataluña, cuyos ciudadanos podrían ejercer el «derecho a decidir» dentro de las reglas de juego, sin romperlas ni violarlas. Y, esperablemente, legitimarían con su voto un orden de convivencia que seguiría siendo España para una próxima generación.

d) Históricamente, last but not least, el referéndum de reforma constitucional cumpliría la función de certificar el acto de maduración democrática de la sociedad española. Superando un historial de disrupciones traumáticas, acometiendo, y resolviendo positivamente la reforma de una Constitución en España ipor fin! por las vías establecidas en la propia Constitución.

\section{LA DEFINICIÓN, ESTRATÉGICA: LA SECESIÓN CATALANA COMO AMENAZA, Y LA FORTALEZA PROPUESTA: HACIA UNA NUEVA FUSIÓN DE FEDERALISMO Y CONSTITUCIONALISMO}

Permítaseme recordarlo, puesto que todavía no parece que esté claro a estas alturas: la Unión Europea (UE) no es, ni ha sido nunca, una unión de naciones autoproclamadas, sino una unión de Estados miembros (art.1 TUE en el Tratado de Lisboa, en adelante TL). Aunque algunos llevamos mucho tiempo en el empeño, lo cierto es que este mensaje sólo muy recientemente ha comenzado a hacerse suficientemente audible y lo bastante visible.

La agitación concitada en torno al denominado procés hacia el secesionismo catalán (antes, soberanismo, importando las categorías del proceso canadiense) ha dado lugar a mil debates, espiralizados cada uno en varios círculos concéntricos. Pero si todavía a estas alturas hubiera que rebobinar para sintetizar dónde radica todavía ese equívoco originario - - esa mistificación de la que las demás distorsiones traen causa-, ese sería seguramente el que concierne al llamado «derecho a decidir».

Se trata sin duda de un gran asunto semántico. La lexicología política fabrica de vez en cuando semantemas que se venden solos, y este parece ser el caso. Su aparente irrefutabilidad — «pero ¿cómo?.. ¿Acaso niegas nuestro derecho a decidir?... ¿Y tú te llamas demócrata?»- esconde, sin embargo, perversiones del lenguaje que no deben ser transigidas sin oponer otros argumentos.

Para empezar, no es verdad que la democracia consista en «decidir» cualquier cosa, ni hacerlo en cualquier momento, ni hacerlo de cualquier manera. Para que las decisiones que se adopten desde un cuerpo político colectivo y todas sus vinculaciones puedan ser aceptadas, es imprescindible que lo sean conforme a 
reglas de juego previamente acordadas y por todos asumidas. Cualquier otra cosa nos aboca a la inacabable dinámica de la acción y la reacción.

Pero no. No, no es verdad. Nunca ha sido verdad y sigue sin ser verdad que en democracia podamos «decidir» cualquier cosa en cualquier momento: las leyes democráticamente legitimadas nos protegen, afortunadamente, frente a la arbitrariedad de una decisión — aun cuando sea respaldada por un voto mayoritario- que viole las reglas de juego previamente asumidas para decidir qué, cómo y cuándo. Si como ciudadano o miembro de un colectivo veo mis derechos o intereses conculcados por una decisión no conforme a las reglas vigentes, podré verme abocado a «contradecidir» al día siguiente de esa previa «decisión» con la que no estoy de acuerdo. Lo que incluye mi derecho a organizarme para resistir contra ella, contraatacarla o revocarla, en una espiral sin fin respecto de la violación de la ley que originariamente dio lugar al desafuero.

Desde el punto de vista jurídico, nadie discute hoy que la secesión unilateral de un territorio frente a un Estado miembro de la UE no sólo no tiene respaldo ni asiento constitucional en ningún país de Europa, sino que además conlleva inexorablemente la salida de ese territorio (con todos sus ciudadanos dentro) del ámbito de aplicación del Derecho de la UE. Cualquier pretensión en contrario se incardina en el terreno de la burda propaganda y de la manipulación (arts. 48 y 49 TUE) $)^{16}$.

Un ensayo reciente $-E l$ derecho de secesión en la $U E-$, del profesor Medina Ortega ${ }^{17}$, catedrático emérito de Derecho Internacional, explica de manera precisa, lúcida y clarificadora el historial de precedentes y términos de comparación que permiten concluir sin sombra de duda alguna que ni el Derecho Europeo alienta ni consiente la permanencia en la UE en un territorio que incursiona en la declaración unilateral de independencia. $\mathrm{Ni}$ es tampoco indolente ante la integridad territorial de los Estados miembros en cuanto éstos forman parte de su propia «identidad constitucional» (art.4 TUE).

De modo que una secesión unilateral del Estado miembro de la UE conduciría a su exfragmento a la condición de «tercero» eventualmente sujeto a las reglas de adhesión, a la negociación de sus 36 protocolos y, tras su completamiento satisfactorio, a nueva incorporación al Derecho Europeo tras superar la unanimidad (es decir, el veto) de todos y cada uno de los socios de la UE (art. 49 TUE).

¡Asombra que haya tenido que producirse una cadena de pronunciamientos explícitos por parte de los portavoces de las autoridades europeas - Comisión y Consejo, con sus respectivos jurisconsultos (jefes de servicios jurídicos) incluidos-

16 Por todos, véase, López Aguilar, J.F.: «Maastricht y la problemática de la reforma de la Constitución», Revista de estudios políticos, n. ${ }^{\circ}$ 77, 1992, pp. 57-94; López CAstillo, A.: La Constitución Europea, Madrid, CEPC/TC, VVAA, 2005; La Constitución de Europa a debate. Estudios constitucionales sobre el complejo constitucional de la UE, Valencia, Tirant lo Blanch, 2005.

17 Medina Ortega, M.: El derecho de secesión en la Unión Europea, Fundación Alfonso Martín Escudero, Marcial Pons, 2014. 
para recalcar lo que es obvio y de dominio público desde los fundamentos de la integración europea!

Ahora, dicho todo lo anterior, el problema político existe y no se va a disolver con meros argumentos jurídicos ni recursos al TC ni con la admonición del artículo $155 \mathrm{CE}$. El genio está desatado y no va a regresar a la botella. Es preciso actuar y hacerlo políticamente. Dialogando, tendiendo puentes para la negociación y el acuerdo.

El inmovilismo del PP en el Gobierno de España (2011-2015) solo puede ser enjuiciado a estas alturas como netamente reaccionario. Por refractario a los cambios cada vez más presentidos como simplemente inevitables por una amplia mayoría de la sociedad española.

Y por contraproducente respecto a la ya impensable desactivación sin más del malestar real que ha venido germinando en una parte muy extensa de la sociedad catalana respecto del status quo.

En cambio hay una propuesta que quiere reconstituir federalmente España, y en la que su identidad nacional y pueblos pueden seguir conviviendo. La federalización de la Constitución — con una revisión profunda de los pactos del 78- es la tarea y el tema impostergable de nuestro tiempo, para decirlo con Ortega. Y somos varias las generaciones que debemos involucrarnos a fondo en su prosecución y su éxito. Nos va en ello la razón de ser de España y, como consecuencia, la de su propio papel en el reflotamiento del federalismo en Europa.

Federalismo y constitucionalismo son dos procesos dinámicos que se han desenvuelto estrechamente vinculados en la historia. Así se reveló en el origen de los EE UU, primera gran democracia constitucional del mundo. Así habrá de serlo, a mi juicio, una vez más en España, y en Europa, en un futuro aun no escrito ${ }^{18}$.

\section{EL MARCO CONCEPTUAL, REVISADO}

Merece la pena, al respecto, detenerse aquí un momento para revisar percepciones extendidas en España que, no obstante su asunción más o menos preconsciente o acrítica, no resisten un examen mínimamente riguroso.

Aunque durante décadas se hizo dominante en España la asunción de esa premisa, lo cierto es que ni el federalismo ni el republicanismo son ideologías de izquierda. Ambas se prestan a ese equívoco en España debido a razones históricas y psicológicas: tanto una como otras formulaciones políticas se asocian en nuestra historia a formaciones progresistas y a sus impulsos de cambio político, es cierto. Pero ni una ni otra prefieren ni discriminan por principio las posicio-

18 Cfr. Biscaretti Di Ruffia, P.: Diritto Costituzionale comparato, Giuffré, Milán, 1984; De VergoTTini, G.: Derecho constitucional comparado, Espasa-Calpe, Madrid, 1983; García-Pelayo, M.: Derecho constitucional comparado, Madrid, 1950.

UNED. Teoría y Realidad Constitucional, núm. 37, 2016, pp. 273-308 
nes políticas que tradicionalmente consideramos distintivas de la derecha y la izquierda.

Así lo muestra la evidencia empírica disponible, tanto bajo la óptica del Derecho y la política comparada como también, incluso, desde nuestra propia historia cuando leemos con detalle y no superficialmente.

En efecto, el federalismo propugna una articulación jurídica de la complejidad, integrando en un todo estructurado y unitario la diversidad de sus partes. La historia de los EEUU, Alemania, Suiza, Austria, Australia, Canadá y otros entes políticos federales muestra con claridad que la solución federal no es en sí conservadora ni progresista, sino fruto de un acuerdo de integración y convivencia en distintos escalones de poder territorial, susceptible de lecturas y aplicaciones ventajosas desde la derecha y la izquierda. Tanto si los Estados federales proceden históricamente de la agregación de entidades territoriales preexistentes (EEUU, Alemania, Suiza, India...) como de la descentralización de Estados antes unitarios (España, Bélgica, Australia...), el federalismo añade valor constitucional al pacto para vivir juntos porque el reconocimiento de las identidades compatibles y la garantía de las competencias y recursos financieros para ejercerlas son asumidos en la propia Constitución común. Por eso federalismo y constitucionalismo son principios vinculados en la historia y la experiencia. ¡Por llamativo que parezca, con una descentralización comparable al arquetipo de un Estado federal, estas son todavía las horas en que ni las identidades, ni las competencias, ni la financiación de las CCAA aparecen recogidas en la Constitución española de 1978 sino, casi 40 años después, en los EEAA, en las leyes y en la jurisprudencia del TC! ${ }^{19}$

Por su parte, el republicanismo expresa, históricamente, la apuesta por una solución no hereditaria frente al problema político de la asignación de la jefatura del Estado. No exhibe, pues, en teoría, ningún marchamo ni ADN izquierdista por sí mismo. Ideológicamente, el republicanismo refuerza la separación de poderes, sus frenos y contrapesos y el carácter electivo y la responsabilidad en todas las instituciones. Más contemporáneamente, los valores del

19 Véase Albertí Rovira, E.: Federalismo y cooperación en la República Federal Alemana, CEC, 1987; Arroyo Gil, A.: El federalismo alemán en la encrucijada: sobre el intento de modernización del orden federativo en la República Federal de Alemania, CEPC, Madrid, 2006; La reforma constitucional del federalismo alemán, Barcelona, IEA, 2009; Biglino CAMPos, P.: Federalismo de integración y de devolución: el debate sobre la competencia, Madrid, CEPC, 2007; CASTellà, J. M.: «La evolución político-constitucional de Canadá». En Mitjans, E. y CaSTELLÀ, J.M (Coords.): Canadá. Introducción al sistema político y jurídico. Barcelona: Publicacions de la Universitat de Barcelona, col-lecció Canadiana 01, 2001, pp. 27-55; Esteban Campos, C.G.: Devolution y forma de gobierno en Escocia, Madrid, CEPC y Vito Breda, «la Devolution de Escocia y el referéndum de 2014: ¿cuáles son las repercusiones potenciales en España?». En teoría y realidad constitucional, n. ${ }^{\circ} 31,2013$, pp. 69-88; GAGNON, A-G.: Quebec y el federalismo canadiense, Madrid, CSIC, 1998; LóPEZ AGUILAR, J.F.: «Quebec \& Roc: una crisis constitucional (actualización del debate canadiense)», Revista Catalana de Derecho Público, n. ${ }^{\circ} 23$ de julio de 1998; SaIz Arnáiz, A.: Estado federal y «estatuto particular, Madrid, IVAP-Marcial Pons, 1997; SMITH, D.E.: Federalism and the Constitution of Canada, Toronto, University of Toronto Press, 2010; WoeHrLING, J.: «El sistema federal de Canadá: origen, evolución y problemas actuales», Teoría y Realidad Constitucional, n. ${ }^{\circ} 28$, pp. $431-460,2011$. 
republicanismo cívico — deliberación, dación de cuentas, transparencia, redistribución del poder y no dominación- son no sólo compatibles con la monarquía parlamentaria (como arquitectura simbólica, desprovista de poder político) sino que representan un mejoramiento de la calidad democrática sea cual sea la opción constitucional elegida para la magistratura encarnada por un Jefe del Estado en países democráticos.

Dicho con toda claridad: ni para propugnar valores republicanos ni para ser favorable a una racional y saludable federalización de España hace falta ser de izquierdas. ¿Se pude ser republicano o federalista y al mismo tiempo de derechas, gente conservadora? Por supuesto que sí.

Para responder que sí basta con evocar figuras como Eisenhower o Nixon en EEUU, Tiers o De Gaulle en Francia, Adenauer o Kohl en Alemania, De Gasperi o Andreotti en Italia... La sola pregunta sonaría directamente estúpida de no ser porque en España una y otra propuestas han debido confrontarse con una hegemonía histórica de despotismo y/o autoritarismo bajo la forma política de una monarquía centralista, en modo que republicanismo y descentralización dieron la mano a la insurgencia y/o a la rebelión contra el binomio de su opuesto. Pero lo cierto es que ni Nicolás Salmerón, ni Estanislao Figueras, ni Emilio Castelar, ni Niceto Alcalá Zamora, ni Alejandro Lerroux... (por mentar sólo ejemplos) fueron ideológicamente personalidades de izquierda en el momento de asumir sus cargos y responsabilidades durante las experiencias de la I República (1873) y la II República (1931-1939).

El propio Manuel Azaña, cuyo genuino perfil intelectual y político distaba de ser el de un «rojo» ni tampoco un «radical», dejó escrito que, contrariamente al pensamiento establecido, «el problema de España no ha sido el subdesarrollo económico sino el subdesarrollo político». De ahí que gobernantes enamorados de la unidad de España como él mismo o Juan Negrín (su presidente del Consejo durante los años finales de la Guerra Civil) hubiesen debido optar por el republicanismo y la descentralización que en España equivalían a modernización frente a la reacción, frente a la revolución y frente al secesionismo de los nacionalistas. También por ello en España es especialmente clara la contraindicación entre el federalismo y el independentismo. Como lo es, por cierto, entre el nacionalismo identitario y los valores del republicanismo cívico.

Lo mismo sucede si enfocamos el período más reciente, desde la Transición hasta hoy. Por señalar un ejemplo, el abogado García Trevijano —que se autoerigió en España como arquetipo de republicanismo disidente del consenso que legitimó, por medio del referéndum de la Constitución, la monarquía parlamentaria - distaba de ser un izquierdista. Tanto como distan ahora muchos capitanes mediáticos que compiten entre sí por su hostilidad a la Corona.

En cuanto al federalismo, insisto, procede subrayar con fuerza que no es tanto una ideología como una experiencia histórica de distribución constitucional de competencias. Del mismo modo que las Constituciones establecen una democracia abierta a la alternancia de gobiernos de distinto signo político — de derechas 
o de izquierdas o mediopensionistas-, la Constituciones federales se abren también a distintas hipótesis ideológicas, políticas y sociales. En los EEUU han sido posibles los gobiernos más rabiosamente conservadores, e incluso que éstos propugnasen una visión volcada a la devolución de poderes a los Estados en detrimento de la capacidad cohesiva o correctora que corresponde la Unión ( Washington», Federal Government, como en Alemania el Bund). En la UE un alto número de Estados republicanos y/o federales (Alemania, Austria, Italia...) en los que las oleadas descentralizadoras han venido impulsadas por formaciones escoradas a la derecha ${ }^{20}$.

¿Por qué cunde en tantos estratos de la sociedad española la percepción de que el republicanismo es de izquierda... y el federalismo también? Insisto: es éste un reflejo psicológicamente condicionado, mezcla de prejuicio y resabio, por la asociación específica que en nuestra historia han tenido las propuestas de uno y otro como motores de cambio en la oposición progresista al monarquismo centralista. Pero también, hay que añadir, por la anomalía distintivamente española que supone que en nuestro país la derecha se haya caracterizado por una resistencia al cambio rayana en el inmovilismo reaccionario.

Desde el Bunker y la caverna (metáforas que describieron los bastiones de la extrema derecha política y mediática durante la Transición y la consolidación democrática) hasta llegar a la actual actitud mayoritaria en un importante segmento de la derecha española, prima ahora y todavía una lectura cerrada de la Constitución de 1978 que hace ya tiempo que perjudica la capacidad integradora que debería preservar la norma fundamental. Permítaseme la crudeza: hace décadas que buena parte de la derecha española que no sólo no votó sino que votó no a la Constitución ha optado por confiscarla —aun sin haberla leído, o sin practicar sus valores - para agredir con ella, como si fuera un martillo, a cuantos estigmatizados como «herejes», «desleales» o desafectos al régimen constitucional pretendan o propugnemos su reforma o revisión. Su cosificación y petrificación ha impedido a la Constitución - de la mano de una hegemonía conservadora en la política española, además de en los poderes económicos, financieros y mediáticos- mantener fresca, no ya intacta, tanto su fuerza vinculante como su adhesión afectiva ante segmentos crecientes de desafección ciudadana. No solamente en Cataluña, es obvio, sino en el resto de España ${ }^{21}$.

Urge acometer el debate sobre la federalización del Estado de las Autonomías y la republicanización de la actual monarquía parlamentaria con una mayor seriedad en el manejo de las categorías. Tanto para afinar en la eficacia transformadora de las reformas constitucionales que tenemos el derecho y el deber de debatir

20 Blanco Valdés, R.L.: Los rostros del federalismo, Alianza, Madrid, 2012; Taylor, CH.: «Valores compartidos y divergentes», en Fossas, E. y ReQuejo, F., Asimetría federal y Estado plurinacional, cit., pp. 37-68.

21 Lopez Aguilar, J.F.: «Constitución, Estado autonómico, reformas estatutarias y Plan Ibarretxe», en Constitución, estado de las autonomías y justicia constitucional: libro homenaje al profesor Gurmesindo Trujillo, coord. por Luis Aguiar de Luque, pp. 1093-1106, Tirant lo Blanch, 2005. 
- antes de que sea tarde-, como para ensanchar el espectro de los actores convocados a esta conversación, que llama a las generaciones vivas y a sus representantes políticos y sociales.

Va siendo hora de que esa porción del conservadurismo español tan refractario hasta ahora se abra por fin a discutir —o por lo menos a hablar- de federalismo y republicanismo como respuestas políticas dignas de ser discutidas, y cuyas propuestas concretas puedan prestarse a acuerdos en los que sus valores y posiciones distintivas puedan desempeñar un papel relevante. Como sucede en los países con más alto nivel de desarrollo político, ciudadanía, cultura cívica y calidad democrática ${ }^{22}$.

\section{EL APREMIO DE LOS TIEMPOS: ¿ESTAMOS LOS ESPAÑOLES A TIEMPO DE FEDERAR?}

Si recordamos el todavía reciente intercambio epistolar, en medios de prensa escrita, entre Felipe González, Duran i Lleida, Artur Mas y otros destacados referentes políticos y de opinión acerca del imponente punto de no retorno al que parece haberse llegado en el «laberinto catalán» (véase en El País, del 30 de agosto al 6 de septiembre de 2015) no es difícil concluir que la malaise democrática desatada por el pésimo (y abyecto, por antisocial) manejo de la que Gran Recesión europea (la que arrancó en 2008, la peor crisis de la UE) ha reverdecido una vez más esa cuestión constitucional medular e inveterada en España donde las haya habido desde siempre: es la vexata quaestio del encaje «singular» de la «identidad» catalana (y su reconocimiento como nación compatible con la Nación española) en la Constitución.

Como tantas otras veces, durante más de un siglo, ha vuelto a discutirse a fondo - y de qué modo - sobre ello. La polémica acerca de la atribución de una apuesta por parte de Felipe Gonzalez por asumir de una vez que «Cataluña es una nación», y hacerlo en la Constitución, reavivaba una vez más la recurrente controversia sobre el concepto mismo de lo que sea una nación. De nuevo, hemos citado profusamente a Sieyès, a Renan, a Ortega y a su memorable polémica con Azaña. Y, una vez más, sobre la validez de la vía federal para favorecer ese encaje.

De modo que no sorprenda que reaparezcan antiguos equívocos e incomprensiones acerca del arquetipo del Estado federal y sobre lo que signifique exactamente «federal». Y particularmente sobre su compatibilidad (o no) con «asimetrías» en su seno.

22 Me remito, al respecto, a mis anteriores escritos: López AguiLAR, J.F.: Estado autonómico y hechos diferenciales, CEPC, Madrid, 1998; Lo constitucional en el Derecho: sobre la idea e ideas de Constitución y Orden Jurídico, CEPC, 1998.

UNED. Teoría y Realidad Constitucional, núm. 37, 2016, pp. 273-308 
Habrá que recordar otra vez que no existe un «canon federal» sino experiencias federales. Como ha mostrado el profesor Roberto Blanco Valdés en uno de sus ensayos lúcidos y decisivos (Los rostros del federalismo; Alianza, 2014), el federalismo tiene y muestra tantos y tan variados rostros como ordenamiento y Estados federales han existido y existen en la realidad de las cosas. Desde los puntos de vista histórico, cultural, político, sociológico —e incluso la arquitectura económica y fiscal de sus recursos financieros- no han existido ni existen dos «federaciones» idénticas: cada una es consecuente con sus supuestos y su historia, todas irrepetibles y basadas en sus propias formulas constitucionales ${ }^{23}$.

Y habrá que repetir de nuevo que «federar» es unir, no lo contrario: no es «disgregar», «centrifugar», que es como, por prejuicios psicológicos arraigados, se ha distorsionado en España la virtualidad «federal».

Y habrá que repetir de nuevo que no es verdad, nunca lo ha sido, que un supuesto arquetipo de «federalismo asimétrico» sería una contradicción o un oxímoron, como si todo federalismo exigiese «simetría» o uniformidad de sus partes. Al contrario: cuando se les observa lo bastante de cerca, todos los federalismos son en su interior asimétricos: Texas no es igual a Rhode Island; Bremen no es Baviera; Queensland no es Tasmania; Quebec no es Saskatchewan.

El sustrato material de cada singularidad puede ser la especificidad lingüística o cultural; o puede ser económica o fiscal, o puede ser geográfica (ciudades-estado, o archipiélagos....). ¡Pero existe! En todos y cada uno de los Estados federales hay rasgos de asimetría, y también los hay en la España de las Autonomías: así, el Concierto Vasco, el Convenio Navarro, las lenguas, la foralidad, el hecho insular, el REF canario... incluso Ceuta y Melilla ${ }^{24}$.

Resulta por eso increíble que todavía a estas alturas se alegue que es un tabú reconocer expresamente la incorporación, de una vez, de una mención específica a la singularidad de Cataluña en la Constitución Española.

Lo he escrito en muchas ocasiones: antes de la modificación del artículo 135 CE de 2011 no existía en toda la Constitución una sola referencia a Europa, ni a la UE, ni al Derecho Europeo. Solo después de esa reforma se ha incorporado una referencia a Europa en el texto de la CE.

Pero estas son las horas en que no existe todavía en la CE ni una sola referencia a Cataluña (sí aparecen mencionadas las provincias vascongadas (D.T. 2. ${ }^{\mathrm{a}}$ y Disp. Derogatoria 1. ${ }^{a}$ ), Navarra (D.T. 4 CE), Canarias (D.A 3 CE), Asturias —Principado de Asturias- (art. 57.2 CE), Ceuta y Melilla (art. 69 y D.T. 5 CE))... ¿Por qué no habríamos de reconocer la singularidad en Cataluña,

23 Ver Blanco Valdés, R.L.: El valor de la Constitución: separación de poderes, supremacía de las leyes y control de constitucionalidad en los orígenes del estado liberal, Alianza Editorial, 3. ${ }^{a}$ ed., 2006; Los rostros del federalismo, Alianza, Madrid, 2012; Biglino Campos, P.: Federalismo de integración y de devolución: el debate sobre la competencia, Madrid, CEPC, 2007; CAMARA Villar, G.: «El principio y las relaciones de colaboración entre el Estado y las Comunidades Autónomas», Revista de Derecho Constitucional Europeo, n. ${ }^{\circ}$ 1, 2004, pp. 197-240.

24 De nuevo, López Aguilar, J.F.: Estado autonómico y bechos diferenciales, CEPC, Madrid, 1998. 
la pujanza de su lengua, su contrastada identidad lingüística cultural, y la pugnacidad de su voluntad de autogobierno?

Cuanto antes lo hagamos, será mejor para todos. Cuanto antes lo reconozcamos todos los demás españoles, mejor para el «reenganche» constitucional, emocional y afectivo de Cataluña en España. Mejor para la integración constitucional española. Mejor para la convivencia de los catalanes entre sí y de los catalanes con el resto de los españoles. Y mejor para las identidades compatibles de los propios catalanes como españoles y europeos.

Una ponencia y un debate de reforma constitucional extensa, con vocación federal, es el contexto adecuado para acometer esta cuenta pendiente con la cuestión constitucional más importante del momento, y de cuantos momentos nos han precedido hasta ahora. Con altura de miras y visión de la jugada. Con liderazgo ante el riesgo. Con ese sentido de la historia que azuza el olfato ante el viento que presiente el huracán.

El tiempo de federar requiere reconocer la identidad nacional de las «nacionalidades» a las que ya se refiere el artículo 2 CE —que, no se olvide, está en vigor desde hace 37 años--, asumiendo de una vez que tanto en castellano como en catalán como en román paladino, la idea de «nacionalidad» denota un predicado de «nación». Sin que ello comporte atribuir a esa «nacionalidad» predicada de «nación»o «identidad nacional»o «realidad nacional» (como proclama, por cierto, el vigente Estatuto de Autonomía de Andalucía), ninguna soberanía política ni sobre la estatalidad ni sobre el Estatuto básico de una ciudadanía basada en la igualdad de derechos.

Y el tiempo de federar requiere hacerlo en la Constitución. Esa es la tarea pendiente, necesaria e inaplazable para salir entre todos de un laberinto de ultimátums, recursos jurisdiccionales, bloqueos, choques de trenes, polos opuestos y enfrentados que se retroalimentan desde el achique de espacios contra la razón dialogada que debe fundar la convivencia en toda Constitución que asegure la igualdad en la diversidad.

\section{EL HORIZONTE: EL FUTURO DE CATALUÑA NO ES EL SIGLO XVIII, SINO EL SIGLO XXI}

El anuncio efectuado en su día, noviembre de 2014, por parte del President de la Generalitat de Catalunya, Artur Mas, acerca de su intención de convocar un referéndum de autodeterminación, bajo el disfraz de una «consulta» sobre el «derecho a decidir», no debió en ningún momento ser despachado con brocha gorda, ni sorteado mucho menos con las luces cortas de la diatriba electoral, como tampoco conjurado sin más echando mano de argumentos procesales y formales. No era ni fue ninguna «broma». Sí, semejante dislate fue la coronación de una hoja de ruta en todo disparatada, pero los daños causados sobre el conjunto de España y sus supuestos constitucionales son del todo reales. 
De un lado, las fuerzas que en aquel momento sostenían al Govern de la Generalitat parecían apostar por ganar un tiempo útil en el cortísimo plazo - para aprobar sus Presupuestos, más antisociales que nunca- al mismo tiempo que aplicaban una vuelta de tuerca adicional a su prolongada salmodia de victimismo ramplón («en España no nos dejan decidir»). Paralelamente, por otro lado, se incrementaba la presión sobre ese sector más conservador la derecha española al que desde el secesionismo catalán se estigmatiza instalada una suerte de «constitucionalismo resistencial» $\mathrm{o}$ «converso» frente al «irredentismo» de los soberanistas, como si la interposición de recursos ante el TC (con su consiguiente efecto paralizador de cualquier convocatoria ilegal por inconstitucional, artículo 161.2 CE y Título V LOTC) fuese por sí sola una respuesta definitiva al «problema». No lo es. Cuando nos despertamos, el dinosaurio continúa estando allí, y tenemos que afrontarlo.

Permítaseme insistir de nuevo. No es cierto que la democracia consista en decidir sobre cualquier cosa, de cualquier modo, en cualquier momento, con desprecio de los tiempos y los procedimientos. Sin reglas de juego para la convivencia, no hay decisión por mayoría que pueda ser aceptable: no lo será si viola los derechos de las minorías y de los ciudadanos; no lo será si viola la garantía de los derechos fundamentales en riesgo. Pero es democráticamente como tenemos que abordar y resolver este reto. El más grave pulso independentista al que hayamos asistido desde que hay democracia en España.

La independencia de Cataluña no debe ser decidida, ni en este caso ni en ninguno, en una fractura binaria de la sociedad catalana. No es una confrontación de «Cataluña contra España», ni tan siquiera lo es «contra el resto de España». Es una confrontación entre catalanes: entre los que exaltan su identidad contra cualquier otra, y los que desean vivirla y disfrutarla en su compatibilidad abierta a otras identidades múltiples: territorial, nacional, europea, internacional y global.

¿Qué harán los independentistas para acomodar los derechos de quienes votasen que no a la/s pregunta/s que les fuerzan a escindir su identidad? ¿Qué harán los derrotados el día siguiente de la «consulta»? ¿Aquietarse, organizarse, resistir, contraatacar, emigrar, abandonar Cataluña o cambiar de pasaporte?

Las hechuras de la convivencia entre españoles y en España se enfrentan hoy a un desafío como no habíamos conocido y hay que rehacerlas. Reinventar la Constitución y el modelo de Estado es una tarea impostergable, requerida de estadistas de mirada larga, con una visión histórica y un enorme sentido de la responsabilidad.

No es el momento de hacerse trampas en el solitario, ni de abundar en tan cansinos regates de cortísimo plazo. Llegados a esta situación, de la que resulta imposible condonar su enorme cuota de responsabilidad al propio President Mas, de poco servirá limitarse a explotar electoralmente discursos más o menos hinchados de «unidad de España», como si bramarlo en plazas de toros disolviese o resolviese por sí solo el malestar real que ha ido acendrándose en buena parte de la sociedad catalana, que es una realidad plural y en conflicto consigo misma, como lo son todas las sociedades democráticas. 
Tras las elecciones catalanas del 27-S de 2015, es claro que Junts pel Si CDC, ERC, ANC - además de la CUP (y con ellos buena parte de los medios de comunicación enfeudados en la regadera de la financiación institucional, más decisiva que nunca en la interminable crisis), han apostado claramente por seguir exasperando la confrontación ramplona como si la «estatalidad» de una autoproclamada y fatua «República Catalana» inaugurase una «aurora dorada» en la que sólo por eso desaparecerían todas las desigualdades, ajustes de cuentas contra el Estado social, abusos de poder y corrupciones que se han exasperado - en Cataluña y en toda España- a rebufo de la crisis que arrancó en 2008.

Parece, por el contrario, que es éste uno de esos momentos en los que merece la pena liderar en serio - con una política de Estado requerida de estadistas como la copa de un pino-- una gran operación de reforma constitucional que haga por fin y de una vez lo que no fue posible hacer hace 37 años, en 1978: constitucionalizar la estructura del Estado y reconocer en ella los hechos diferenciales y sus singularidades constitucionalmente relevantes. Habrá que acomodar Cataluña en una España federal, con todos los catalanes y los demás españoles a bordo, dentro de un proyecto común de convivencia, con nuevas reglas de encaje (cláusulas identitarias, competencias, financiación) abiertas a la conjugación de una ciudadanía catalana, española y europea, comprometida con el mundo en la globalización ${ }^{25}$.

De modo que, así las cosas, las elecciones catalanas del 27-S de 2015 fueron inevitablemente algo más que unas elecciones autonómicas ordinarias. Fue obvio que debieron surfear un mar encrespado de problemas constitucionales. En su trasfondo, la cuestión de la integración constitucional de la singularidad de Cataluña. Pero transpirando también la de la ciudadanía de identidades compatibles (no segregadas, ni excluyentes). Y, en el horizonte de reforma de la Constitución, la ocasión de plantear la evolución federal de lo que ha dado en llamarse Estado de la Autonomías. Y de la mano del reconocimiento del carácter nacional de Cataluña, suscitan la compatibilidad de una nación lingüística y cultural catalana (de la que se predica la «nacionalidad» del art. 2 CE) con la Nación española en la que se residencia la soberanía popular de todos los españoles.

Afirmado lo anterior, no se puso, sin embargo, énfasis suficiente en un problema democrático planteado en estos tiempos de tensión secesionista a rebufo de la vía políticamente elegida por los secesionistas: el de la transmutación de las elecciones autonómicas que debían tener lugar aquel 27-S de 2015 en un virtual «plebiscito de secesión unilateral de Catalunya» mediante su declarada conversión en «elecciones plebiscitarias».

Sostengo que este concepto de «elecciones plebiscitarias» es un oxímoron, conceptualmente inaceptable, contradictorio en sus términos. La razón es taxativa: en la democracia constitucional (la única que merece el nombre), las elecciones se diseñan y realizan para institucionalizar una escala representativa del pluralismo po-

25 López Aguilar, J.F.: Estado autonómico y hechos diferenciales, CEPC, Madrid, 1998.

UNED. Teoría y Realidad Constitucional, núm. 37, 2016, pp. 273-308 
lítico y de la complejidad de una sociedad abierta, no de su negación ni de su anulación, ni su oposición binaria ni su reducción ad absurdum. No caben, pues, elecciones que anulen el pluralismo de las opciones en disputa, que hurten el pluralismo a la conversación democrática y a la representación que dimana del sufragio.

Para empezar, un plebiscito no equivale a un referéndum. Comparte con el referéndum la práctica de una pregunta por la que se divide a la ciudadanía -el cuerpo electoral, los votantes- sobre una bisectriz: sí o no. Como sucede con el referéndum, todo plebiscito persigue reducir la dialéctica de lo complejo a una confrontación entre dos segmentos de la sociedad, obligados a escindirse sin negociación ni síntesis. Por ello mismo prescinde del trabajo que corresponde a la representación. Los representantes abdican de su función distintiva: articular la suma de una provisional voluntad mayoritaria desde la pluralidad social. El referéndum se convoca para ratificar (o no) una decisión política, legislativa o no. Y se traslada así con ello a la ciudadanía la fatiga de escindirse que el Gobierno representativo podría haberles ahorrado. Pero el plebiscito, además, diferenciadamente, introduce un giro de tuerca de adicional carga añadida: lo convocan los Gobiernos para autolegitimar tanto la decisión ofertada como la ejecutoria del poder que lo convoca. Se distingue por cuanto revela, paladinamente, la intención de quien convoca de instrumentalizar el resultado en su propio beneficio, no la de «consultar» ni «oír» al «pueblo» en lo que quiera que decida.

Precisamente por esa dimensión "plebiscitaria» con que la historia nos ha advertido acerca de la desviación del referéndum en experiencias de abuso de poder propagandístico y manipulativo, la Constitución española del 78 acogía el referéndum (en sus «distintas modalidades», a las que se refiere el art.92 CE) sólo con grandes cautelas.

Porque recuerda bien los plebiscitos de Franco (los convocados y ganados «masivamente» en 1947 y 1966). Porque recuerda bien los plebiscitos convocados y ganados por gobiernos antidemocráticos a lo largo de la historia (¡incluso Hitler convocó y ganó uno, por los «plenos poderes», en 1934!). Y porque recuerda bien el surgimiento de la técnica del «plebiscito golpista», vinculada al «cesarismo plebiscitario» y al «bonapartismo», no por Napoleón I (Emperador de Francia 1804-1815), sino por aquel Louis Napoleón llamado Napoleón III, único presidente de la II República Francesa (1848) autoproclamado, después ipor vía plebiscitaria! Emperador de los franceses durante el II Imperio (1851-1870).

De modo que esa noción misma de «elecciones plebiscitarias» no solamente encierra un aberrante neologismo. Es que incorpora, además, una grosera e inconfesada negación del mismo concepto de democracia. Porque al reducir del espectro político del pluralismo intrínseco a una sociedad democrática y abierta a la disyuntiva binaria de un «sí niega la decisión política que corresponde a una elección: la de una mayoría capaz de plasmar un mandato responsable para conformar un Gobierno. Y una legislación capaz de garantizar el principio democrático de la revocabilidad de todas las decisiones a través de la (periódica) cesación del consentimiento de los gobernados, 
traducido eventualmente en cambio de mayoría (y revocación del mandato representativo anteriormente decidido).

Pero lo cierto y real es que nada de esto ha sido casual ni inocente. Al imponer su lenguaje, los secesionistas catalanes marcaban así un punto álgido en su designio estratégico hacia la hegemonía de la llamada «narrativa» y «épica» del debate político con un ejercicio trilero que trastocaba los conceptos mediante el espejismo de un fraude lexicológico: la identificación de un sedicente y autoproclamando (pero en rigor inexistente) «derecho a decidir» su futuro... ¡ a la postre subrogado por una «elección plebiscitaria»!

Pero la secuencia de premisas asumidas para apuntar ese objetivo respondía en todo momento, y continúa respondiendo, a una grosera falsedad: no sólo porque, tal y como he subrayado, no es verdad, nunca lo ha sido, que la democracia equivalga, sin más, a «decidirlo todo» por votaciones ordinarias. Ni menos aun que equivalga a «decidir» cualquier cosa de cualquier modo y en cualquier momento. No: ni siquiera es verdad que la «democracia» se reduzca al «gobierno de la mayoría». La democracia es también, y sobre todo, protección y garantía de la(s) minoría(s). Y el respecto - innegociable - a los derechos fundamentales que aseguran la soberanía irreductible de la persona —el individuo — frente a cualquier mayoría.

Y es que, también, y sobre todo, democracia es decidir conforme a reglas de juego, previamente pactadas, aceptadas por todos y cada uno de los titulares de ese espacio compartido de «soberanía» del que toda decisión trae causa al mismo tiempo que la acota. Y esas reglas de juego — las que nos hemos dado, todavía hoy en vigor hasta la «nueva orden» en que decidamos otra cosa - no permiten traducir ningún mandato (siempre, por definición, circunstancial y reversible) en un «plebiscito» orientado a la autolegitimación ilimitada e indefinida de ningún Gobierno que aspire a llamarse democrático. Menos aún si no repara en fracturar o dividir a una sociedad plural. Ni en el daño que ello irrogue al orden (reglas de juego) por el que Cataluña da cuenta de sus identidades, encarnadas en millones de catalanes protegidos por su irreductible estatuto de ciudadanía con derechos y libertades iguales en España y en Europa.

Sí, ya lo sabemos, ya lo hemos recordado: mil definiciones compiten a la hora de explicar en qué consiste una nación. Sieyès, Renan, Ortega, Azaña, contendieron intentando dar cuenta de sus fundamentos culturales, socioeconómicos, políticos, financieros...y sobre todo afectivos, emocionales...atinentes al espíritu (Volksgeist) del sentimiento, la psique y los estados de ánimo. En su imperecedero ensayo, Ernest Renan la definió como un «plebiscito cotidiano». Lo que en ningún caso autoriza un plebiscito por el que jen un solo día - por pasional que resulte-— pueda decidirse un «ser» esencial, definitivo, y por ende irreversible, que al día siguiente desampare a quienes votaron $«$ no» ${ }^{26}$. 


\section{CONCLUSIÓN PROVISIONAL: HASTA LUEGO, INDEPENDENCIA, HOLA CONSTITUYENTE CONSTITUIDO}

De modo que, llegados a este punto, procede recapitular sobre la ocasión que se asoma con la Legislatura que nace de las elecciones generales celebradas el 20 de diciembre de 2015, la XI Legislatura de la democracia constitucional. Nada más y nada menos que hacer las Cortes Generales surgidas de esas elecciones una expresión del poder constituyente constituido — poder de reforma, por tanto - previsto en el Título X de la Constitución (arts.166 a 169 CE) ${ }^{27}$.

Lo sabemos. Hace demasiado tiempo que mantener la serenidad del juicio, a pesar y por encima de la calenturienta agitación suscitada por el prolongado envite secesionista en Cataluña - y por la subsiguiente polarización que divide la sociedad catalana y, por extensión, la española-, se ha convertido en un esfuerzo agotador, a ratos incluso heroico.

Pero, como predecíamos, el 28-S de 2015 (día después del 27-S, elecciones catalanas), el sol ha salido de nuevo en Cataluña, pero no ciertamente por Antequera. En efecto, las encuestas habían predicho una mayoría absoluta del soberanismo en escaños, aunque no en votos. Y eso exactamente es lo que ha sucedido. La conclusión ahora es que lo que quiera que fuera su «elección plebiscitaria» trastocada en «plebiscito» lo han perdido quienes convocaron desde el poder.

El resultado no ha sido, en ningún caso, el fin de la historia. De ninguna historia. Ni se ha roto España el día siguiente, ni se ha legitimado en las urnas ninguna - por demás inviable- declaración unilateral de independencia. Ni se han abierto en la UE las aguas del Mar Rojo para recibir a ningún autoproclamado «nuevo Estado miembro» (la virtual/fantasmagórica «República de Catalunya»), ni se ha allanado la Comunidad Internacional a ningún reconocimiento de la estatalidad de ninguna sedicente «República Independiente de Catalunya».

Asumido lo anterior, la situación es muy seria. Distinta a todo lo anterior, más grave que ninguna otra encrucijada anterior en la historia democrática desde la Transición. No puede ser subestimada ni relativizada.

Es cierto que quienes se embarcaron en un insultante sumatorio de trampas plebiscitarias con planteamientos falaces han tropezado con el «no», a la luz de la asimetría en el alineamiento del voto: casi un $53 \%$ de los sufragios expresados ha optado por candidaturas contrarias a la independencia.

Pero también es evidente que nada menos que un $47 \%$ lo ha hecho por candidaturas que habían hecho del mantra soberanista del «derecho a decidir»

Cataluña Selección y estudio preliminar; Tecnos, 2005; SIEYÉs, E.: Escritos y discursos de la Revolución, CEC, Madrid, 1990; Schmiтt, C.: Teoría de la Constitución, Alianza Editorial, Madrid, 1982.

27 Cfr. Pérez-Royo, J.: «Algunas reflexiones sobre el Título X de la Constitución», en Rev. Política Comparada, UIMP, Madrid, 1984, y DE VEGA, P.: VOZ «Reforma constitucional», en GonZÁLEZ ENCINAR, J. J. (coord.): Diccionario del sistema políticoespañol, Akal, Madrid, 1984; La reforma de la Constitución, CD, Madrid, 1987. 
un trampolín de lanzamiento para la «superación» del actual statu quo, cualquiera que sea el radicalismo del horizonte rupturista al que se quiere apuntar. Un conglomerado informe de impulsos contradictorios (el republicanismo de izquierdas de ERC y las oligarquías corruptas de la fenecida CiU y de la CDC) han fracasado a la hora de plebiscitar su imaginaria y contrahecha hegemonía. El independentismo carece de concreción en una acción de Gobierno y en un programa para ello.

De modo que sí, por un lado, la falaz transmutación de unas elecciones autonómicas en un taimado plebiscito queda desautorizada. Pero no menos (sino aún más) queda desarbolada la táctica de avestruz practicada, con diletancia, por el Gobierno de Rajoy y la mayoría absoluta del PP a lo largo de la X Legislatura (2011-2015).

Nunca se subrayará lo bastante su responsabilidad en el deterioro severo de la fuerza integradora de la Constitución que hemos venido padeciendo durante los últimos años. Baste recordar aquel insensato planeamiento y ejecución de un asalto al TC en toda regla (recusación de Perez Tremps: iqué atropello!) con el proclamado objetivo de tumbar el Estatut en 2006, sin reparar en los daños y consecuencias de aquella borrachera de crispación rayana en el anticatalanismo. La cúpula del PP apostó entonces por dinamitar así lo que seguramente fue la penúltima oportunidad de encajar la voluntad de buena parte de la sociedad catalana de obtener un reconocimiento a su singularidad (intensidad de identidad y voluntad de autogobierno) en una España plural cuya arquitectura no puede ser ya sino un Estado federal.

La única forma de política que emerge de este laberinto con una propuesta en positivo, una formulación propia y un horizonte de futuro, es la reforma federal de la Constitución. Porque federar es unir. Y hacerlo en la Constitución. Reunir y reintegrar los elementos y factores del actual polinomio constitucional catalán dentro de un todo integrador que afirme reglas de juego — esto es, reconocimiento, recursos financieros, reparto claro de competencias- para la España autonómica y el reconocimiento expreso de sus singularidades. Ese es el objetivo a estas alturas.

Los secesionistas, pues, no deben salirse con la suya. No ya por argumentos jurídicos —ni menos aún leguleyos—, sino por razones estrictamente democráticas. No bastan ni el populismo y ni la protesta exasperada para reparar y zurcir los descosidos, ni para dar certidumbre a quienes precisan seguridad y seriedad para encarar el futuro a quienes no quieren navegar a oscuras. Pero los más reaccionarios ni los inmovilistas que han venido negándose a reconocer la realidad tampoco pueden liderar el desenmarañamiento de la actual madeja de problemas constitucionales.

Esta XI Legislatura (2015-2019) que arranca en las elecciones del pasado 20 debe por tanto dibujar impostergablemente un nuevo ciclo constitucional. Reforma constitucional es la concreción democrática del poder constituyente que establece el Título X de la Constitución de 1978 (arts. 166 a 169). 
Tiempo habría de ensanchar ese melón una vez que esté abierto. Para reformar, entre otros objetivos plausibles para una sociedad madura, el propio Título $\mathrm{X}$ de la Constitución, el Título de la propia «Reforma», de modo que finalmente, como es la regla normal de las democracias maduras, la Constitución española deje de ser «irreformable», y sea mejorada a impulsos de «reformas» razonadas, y no por «pronunciamientos» ni por rupturas traumáticas como las que tanto daño causaron en el pasado a lo largo y a lo ancho de la abultada peripecia histórico-constitucional española.

\section{EPILOGO: ¿A TIEMPO DE SALVAR AL TC?}

La iniciativa de reforma de la LOTC (LO 15/2015, de 16 de octubre, de reforma de la LO 2/1979, de 3 de octubre, del TC, para la ejecución de las resoluciones del TC como garantía del Estado de Derecho) promovida por el Gobierno y su mayoría absoluta en las atribuladas postrimerías de la pasada X Legislatura (2011-2015) merece, a mi juicio, encaramarse de inmediato al podio de las menos calculadas y más deplorables de toda la historia democrática desde la Constitución de $1978^{28}$.

He denunciado en muchos escritos anteriores la contraproducente contradicción entre el discurso infatuado de muchos que se llenan la boca con las palabras «España», «Constitución» y «Estado de Derecho», mientras con sus actos devalúan, desacreditan o vacían de contenido cada uno de esos activos, y patrimonios colectivos, y los valores que los fundan.

Desde el punto de vista de las formas, suscita rechazo la zafiedad con que una medida que afecta, y de qué modo, nada menos que al TC como «intérprete supremo de la Constitución» (art.1 LOTC) fue anunciada en el Congreso con redoble de tambor por el candidato del PP a las elecciones catalanas del 27-S de 2015, quien ni siquiera, por cierto, era en ese momento diputado en el Congreso. Resultaba, además, especialmente inaceptable que se encubriera taimadamente como una falsa «iniciativa legislativa» del Grupo parlamentario del PP a los solos efectos de esquivar no solo los trámites consultivos preceptivos que se le exigían a la iniciativa legislativa del Gobierno, sino para eludir asimismo toda aconsejable ocasión de diálogo mínimo con los Grupos parlamentarios con representación en las Cortes Generales, que hicieron bien, a mi juicio, en rechazarla de plano.

Desde el punto de vista de su contenido, la reforma de la LOTC finalmente adoptada con los votos del PP (y apósito de UPN) incorpora una grosera reconversión del TC en una suerte de Tribunal administrativo y sancionador de Orden Público. Lo que se propone no tiene nada, pero que nada que ver con ese Derecho comparado de la Justicia Constitucional «concentrada», encomendada a un órga-

28 Véase, por todos la crítica efectuada por Camara Villar, G., y Montilla Martos, J.A: «Insólita reforma», El País, 9 de septiembre de 2015. 
no al que se distingue como «intérprete supremo» de la constitucionalidad de las Leyes y de la conformidad del resto del ordenamiento jurídico a la Constitución. Pretende inyectar, y encapsular, a capón, en el cuerpo del TC, una función policial y sancionadora «de emergencia» notoriamente extraña a su naturaleza y funciones, puesto que no otra cosa añade a las disposiciones ya vigentes de la Constitución (el deber general de acatar y cumplir las resoluciones jurisdiccionales (art. $118 \mathrm{CE}$ ), así como en la propia LOTC (arts. 1 y 4)).

A todas luces: es evidente que a la mayoría absoluta que ideó esta reforma no le bastaba con el instrumentario vigente y potencialmente disponible: ni con el artículo 155 CE, ni con la Ley Orgánica de Estados de Alarma, Excepción y Sitio (LO 4/81, de 1 de junio), plenamente en vigor, ni con la Ley de Seguridad Nacional (Ley 36/2015, de 28 de septiembre), también aprobada en el curso de la X Legislatura. ¡Han tenido que pedirle «un 155» exprés nada más ni nada menos que al TC! Y así lo muestra la secuencia de la Declaración de «desconexión» aprobada por Resolución del Parlament de Cataluña de 9 de noviembre de 2015, impugnada por el Gobierno y suspendida por el TC en auto con fecha de 11 de noviembre de 2015, en cumplimiento con lo dispuesto en los arts. 161.2 CE y 79 LOTC, y finalmente invalidada por la STC de 2 de diciembre de 2015. Para asegurar de ese modo la supremacía de la Constitución no hacía falta introducir con precipitación las medidas de la LO 15/2015 de reforma de la LOTC ${ }^{29}$.

Sentado lo cual debo añadir que me parecieron chocantes las voces que se apresuraron a denunciar tufos «electoralistas» de la medida anunciada. Porque ello suponía dar por sentado, erróneamente a mi juicio, que un atropello así ante una cita electoral inminente —el 27-S catalán — reportaría al PP réditos electorales. No hay prueba ni evidencia de ello, parece bastante evidente. Pero lo más preocupante es que, con tal decisión, parezca como si algunos continuaran empecinados en liquidar el ya menguado prestigio que le resta al TC. Y habrá que recordarlo de nuevo: en una democracia constitucional fundada en una Constitución normativa y jurisdiccionalizada, no hay Constitución que valga si no hay un Tribunal Constitucional con la fuerza persuasiva y la legitimación social precisas para preservarla.

$\mathrm{Ni}$ en Cataluña ni en España puede salir adelante ni puede prosperar ninguna iniciativa que apueste por la desnaturalización de las instituciones vertebrales de la cada vez más fatigada arquitectura del edificio constitucional en España.

$Y$, en fin, tras tres largos años de anunciación secesionista, asombra que todavía haya quien se sorprenda de que nos hallemos en un tris de estamparnos de bruces con la epifanía del 155 CE.

Hemos desempolvado tanto la vigencia de este artículo de la Constitución que duele tener que recordar, a estas alturas del requeteanunciado choque de trenes, que el 155 CE no contempla en ningún caso la «suspensión» de la autonomía de Cataluña:

29 Ferreres, V., Fossas, E. y Saiz Arnáiz, A: Inconsistencias de la «desconexión», El País, 24 de noviembre de 2015 .

UNED. Teoría y Realidad Constitucional, núm. 37, 2016, pp. 273-308 
Si una Comunidad Autónoma no cumpliere las obligaciones que la Constitución u otras leyes le impongan, o actuare de forma que atente gravemente al interés general de España, el Gobierno, previo requerimiento al presidente de la Comunidad Autónoma y, en el caso de no ser atendido, con la aprobación por mayoría absoluta del Senado, podrá adoptar las medidas necesarias para obligar a aquélla al cumplimiento forzoso de dichas obligaciones para la protección del mencionado interés general.

Eso es lo que dice literalmente: por ningún lado hay «suspensión» de la Generalitat ni de la autonomía. Pero no es ninguna broma.

Importado de la cláusula de «coerción federal», y especialmente del recurso a la bundesexecution del artículo 37 de la Ley Fundamental alemana (su Grundgesetzt, Constitución), el mecanismo previsto en el artículo 155 CE debe ser entendido como una garantía coactiva de primacía estatal.

Asegura los poderes del Estado (de la Unión de los EEUU, o del Bund en Alemania) ante la eventualidad de graves incumplimientos de sus obligaciones por parte de las entidades o partes vinculadas por el todo (los estados en EEUU, los Länder en Alemania, las Comunidades Autónomas en España).

Ante una explicable ausencia de desarrollo legislativo de este artículo (por no haber llegado, hasta hoy, al extremo de necesitarla), venimos asistiendo estos días a una exploración prospectiva acerca de los contenidos de su aplicación en la práctica ${ }^{30}$.

La concentración de facultades coercitivas del orden público en las fuerzas y cuerpos de seguridad del Estado emergen como primera opción, inmediatamente sucesiva a toda esa batería de impugnaciones ante el TC, recursos jurisdiccionales ordinarios y las eventuales querellas por desobediencia, desacato o sedición que puedan interponerse contra personas concretas por sus responsabilidades penales individuales en este desaguisado.

Lo más desolador — y más grave— orbita todavía en la pregunta "¿cómo hemos llegado a esto?».

Porque se ha permitido. Era evidente que la desafección y las ganas de confrontación abierta no podían - como el dentífrico no regresa al tubo- ser rebobinadas sin más. No sin que nadie hiciera nada desde esta posición que ha dado en llamarse «unionista», y que debería congregar, no sólo a ese sector conservador empecinado en no mover ficha en nada y conjurar toda amenaza de afrenta unilateral, por real que haya llegado a ser, sola y exclusivamente con técnicas leguleyas y abogados de Estado, sino también a quienes estamos dispuestos a preservar la integración constitucional española promoviendo cambios y reformas acordadas para desatascar en alguna dirección el actual status quo.

Ese impasse en el que hemos estado como sentados al borde de una vía de tren cada vez más minada no ha sido, sin embargo, un escenario de «mutua destruc-

30 García Fernández, J.: «Artículo 155: Instrucciones de empleo», El País, 5 de noviembre de 2015. 
ción asegurada» en que se profesaran creciente animadversión los insensatos secesionistas, de un lado, y los recalcitrantes inmovilistas, de otro.

Lamentablemente, la realidad contrastada es otra: unos y otros han tensado una cuerda que está a punto de romperse sobre las cabezas de millones de españoles sensatos. Y lo han hecho porque han preferido obtener réditos políticos, y aun peor, electorales, de su polarización extrema y su enconamiento recíproco.

Esa es, también, entre otras, una de las amenazadoras sombras de confusión, incertidumbre y angustia que acechan el 20-D. Esa fecha capital en la que los españoles nos jugamos la redefinición de nuestras reglas de juego.

Porque está cada vez más claro que secesionistas e inmovilistas han venido mostrándose penosamente dispuestos a aparcar todo lo que en democracia merece ser debatido — desigualdad, paro, corrupción, entre otros males mayores- para concentrar sus retóricas y energías negativas en confundir ante millones sus responsabilidades, en un historial de Gobierno cuyos estragos sociales y pufos de corrupción están aún hoy recientes en el tiempo.

El gobierno de Artur Mas y sus corifeos secesionistas son los responsables últimos. No hay discusión sobre esto. Culpables de un embolado que sin duda es el más grave al que, desde el 23-F, haya debido enfrentarse nuestra democracia herida.

Alucinantemente, Mas y sus turiferarios aspiran, no solamente a salirse con la suya, sino a recibir la palma de la gloria y del martirio. La buscan, soñándose a sí mismos como reencarnación de Gandhi o Mandela, ignorando que Cataluña no es la India contra el Imperio colonial británico, ni la Sudáfrica del Apartheid, sino una sociedad abierta y plural que hasta hace poco fue referente envidiado de europeísmo y convivencia.

Ni esos recursos y querellas, ni el «falso 155» que se ha incrustado al TC para transmutarlo en una suerte de Tribunal administrativo (o aún peor, de Orden Público) ni el verdadero y genuino $155 \mathrm{CE}$, producen a esos sujetos una fuerza disuasoria en disposición de evitar que hayamos llegado a esto.

Es tal el delirio grotesco en que se han embarcado, que es más que evidente a estas alturas que estos sujetos no temen los recursos y querellas. Pero eso recursos y querellas es lo que se vino anunciando con redobles y tambores duramente demasiado tiempo por quienes parecen pensar que todo se arregla invocando una y mil veces el estado de Derecho y el Imperio de la Ley democráticamente legitimada y subordinada a la Constitución; por supuesto, faltaría más: Estado de Derecho, Constitución, democracia... y TC, claro que sí.

Pero, además de todo eso, hará falta algo más.

TITLE: Catalonian question and constitutional crisis

ABSTRACT: The constitutional structure launched in Spain in 1978 is facing dire straits. After almost 40 years, it needs to be rebabilitated, and that demands its reformation. To strengthen the democracy 
—injured, as well as the rights, by the management of the so called «European Great Recession»-, to restore trust in politics and to relaunch at the same time its ability to integrate the plurality and the conflict, are all objectives that require a constitutional pact which updates the previous one closed long time ago, as well as a federal pact which assumes the maturing of our identity diversity, which is that of the Spaniards in the first half of the 21st century.

RESUMEN: El edificio constitucional inaugurado en España en 1978 rechina boy por todas las costuras. Tras casi 40 años, urge rehabilitarlo, y eso exige reformarlo. Reforzar la democracia - maltrecha, como los derechos, por el manejo de esta crisis que hemos dado en llamar «Gran Recesión» europea-, restablecer el crédito de la política y relanzar al mismo tiempo su capacidad de integrar la pluralidad y el conflicto, son objetivos que demandan un pacto constitucional que actualice el que se bizo hace ya tanto tiempo. Y un pacto federal que asuma — va siendo hora-la maduración de nuestra diversidad identitaria, que es la de los españoles en esta primera mitad del siglo XXI.

KeY wORDs: Constitution. Democracy.

Palabras Clave: Constitución. Democracia.

FECHA DE RECEPCIÓN: 15.12.2015 FECHA DE ACEPTACIÓN: 15.01.2016 